\title{
Conceptual Hydrogeological Model and Groundwater Resource Estimation in a Complex Hydrothermal Area: The Case of the Viterbo Geothermal Area (Central Italy)
}

\author{
Antonella Baiocchi, Francesca Lotti, Vincenzo Piscopo* \\ Dipartimento di Scienze Ecologiche e Biologiche (DEB), Università degli Studi della Tuscia, Viterbo, Italy \\ Email: "piscopo@unitus.it
}

Received February 1, 2012; revised March 2, 2012; accepted April 2, 2012

\begin{abstract}
The conceptual hydrogeological model of the Viterbo thermal area in central Italy and the yield of the groundwater system have been examined. This area is of great geothermal interest. Through new investigations, three overlapping aquifers have been found. This study examines in detail the two shallower aquifers, characterized by different hydraulic and chemical characteristics. The first aquifer is related to the regional groundwater flow of the Cimino-Vico volcanic system and is generally characterized by cold, fresh waters used for irrigation and drinking water supply. The second aquifer, i.e. the thermal aquifer, supply thermal spas and public pools; it is present where the local hydrostratigraphic, structural and geothermal conditions permit a relatively active flow of higher salinity thermal waters $\left(40^{\circ} \mathrm{C}-62^{\circ} \mathrm{C}\right)$. These two aquifers interact vertically and laterally, giving rise to mixed waters circulating in the first aquifer. The first aquifer is recharged by direct infiltration and inflow from regional groundwater, as well as inflow from the second aquifer. The yield of the thermal aquifer is at least $170 \mathrm{~L} / \mathrm{s}$, discharging into thermal springs and wells, besides feeding the shallow aquifer vertically and laterally. Even if a future development of the second aquifer is potentially achievable on a global scale, the exploitation of the thermal waters is strictly dependent on the specific local hydrogeological equilibrium between the overlapping aquifers, different from place to place. The case study highlights that, in the volcanic hydrogeological environment, one of the most stringent constraints in determining the correct usage of a resource is the variable level of interaction of groundwater with different qualities.
\end{abstract}

Keywords: Volcanic Aquifer; Thermal Waters; Overlapping Aquifers Interaction; Viterbo; Italy

\section{Introduction}

The city of Viterbo is in the Tuscany-Latium geothermal region and is of great geothermal interest [1]. Several thermal springs and wells are present that have water temperatures as high as $62^{\circ} \mathrm{C}$. Some of these springs have been known for their therapeutic properties since Roman times, and wells have been drilled for geothermal exploration since the 1950s.

Currently, these thermal waters are used primarily to supply thermal spas and public pools. In the same area, a shallow aquifer carries cold and fresh water, which is used for irrigation and the local drinking water supply. Increases in spa tourism and the use of geothermal energy are expected in the near future. This multi-purpose water demand also exists for other volcanic aquifers in Italy and around the world e.g., [2-7]. To address the future groundwater management in these complex systems, it is important to examine the local response of the

*Corresponding author. aquifers to withdrawals.

The purpose of this paper is to review the conceptual hydrogeological model of the Viterbo thermal area and to estimate the yield of the groundwater system. This study represents a first step toward determining criteria for the sustainable management of groundwater in this area using a numerical model. Various studies of the Viterbo thermal area have addressed the reconstruction of the stratigraphy and structure, the evaluation of heat flow, the chemical characteristics of gaseous and hydrothermal emissions, and the origin of the thermal waters. However, because of the lack of complete data, few hydrogeological studies have defined the interactions between aquifers and the yield of the system. These aspects are studied herein through new investigations using an integrated approach that combines a hydrogeological and hydrochemical characterization of the complex groundwater system.

\section{Geological and Hydrogeological Outlines}

The study area lies between the Tyrrhenian coast and 
the Apennine Mountains (Figure 1(a)). This region contains a series of sedimentary basins related to the processes that occurred during the formation of the Apennine Chain. Periods of local subsidence alternated with periods of differential uplift and intense volcanic activity have affected the region since the Pliocene [8-11]. Volcanic activity gave rise to the Cimino and Vico complexes (Figure 1(a)); the former is related to the Tuscan-Roman anatectic magmatic province, and the latter is related to the Roman-Campanian potassic alkaline province [12-15].

The Cimino complex was active between 1.35 and $0.95 \mathrm{Ma}$. Effusive and explosive activity gave rise to several domes that developed along a NW-SE trending fracture and included pyroclastic deposits. Rhyodacitic ignimbrites and domes as well as latitic and olivinelatitic lavas constitute the volcanic complex [16-18].
The Vico complex consists of a stratovolcano with a central caldera that houses Vico Lake. This volcano was mainly active between $419 \mathrm{ka}$ and $95 \mathrm{ka}$ and developed along a NW-SE elongated graben at the intersection with a NE-SW fracture. Alternating explosive and effusive phases gave rise to several pyroclastic deposits and lava flows, which are phonolitic, tephritic and trachytic in composition [18-21].

The thickened folded and thrusted substratum beneath the Cimino and Vico volcanics is composed of MesozoicCenozoic carbonate sequences (that are several thousands of meters thick) and siliciclastic turbidite deposits (the Upper Cretaceous-Eocene flysch) [9,10,22-25]. NWand NE-striking extensional faults subdivide the substratum rocks and control the horst and graben pattern. Neogene-Quaternary marine to continental deposits fill the structural low of the Mesozoic-Cenozoic units.
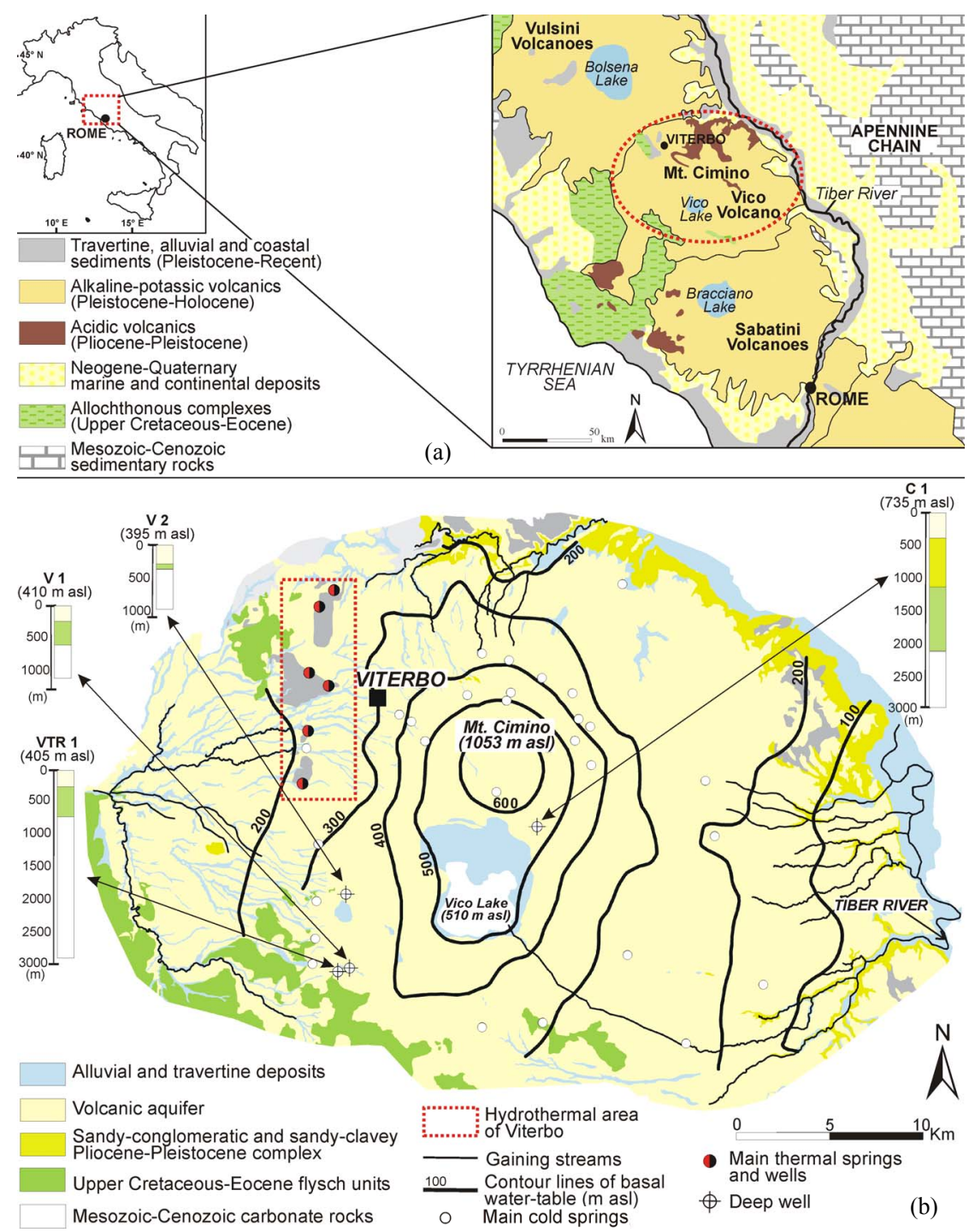

Figure 1. (a) Cimino-Vico volcanoes location in central Italy; (b) Simplified hydrogeological map of the Cimino-Vico system [34] with location of hydrothermal area of Viterbo. 
The thinning of the lithosphere and the related igneous processes affecting the pre-Apennine belt explain the formation of the strong regional heat flow anomaly. Values of heat flow between 200 and $300 \mathrm{~mW} / \mathrm{m}^{2}$ over wide areas and up to $400 \mathrm{~mW} / \mathrm{m}^{2}$ in smaller zones have been recognized [1,26-28].

Substantial $\mathrm{CO}_{2}$ emissions characterize the area and control the genesis of the travertine [29-33] that typically outcrops around the Viterbo thermal area (Figure 1(b)).

The Cimino and Vico volcanites constitute an aquifer system limited by the Pliocene-Pleistocene sedimentary complex and Upper Cretaceous-Eocene flysch units (Figure 1(b)). A continuous basal aquifer and several limited, discontinuous perched aquifers are present [34-36]. The volcanic aquifer discharges mainly into streams and springs, and it flows towards the alluvial aquifer. The mean yield of the volcanic aquifer has been estimated to be between 5 and $7 \mathrm{~m}^{3} / \mathrm{s}$ [34].

In the study area, the Mesozoic-Cenozoic carbonate rocks are considered to be a deep aquifer hosting a thermal reservoir [26,37-38]. The shallow and deep aquifers are separated by thick low-permeability Pliocene-Pleistocene and Upper Cretaceous-Eocene sedimentary rocks. West of Viterbo, the uplift of the basement of the volcanites and the high heat flow are considered to be the origin of the uprising of thermal waters via faults and fractures (Figure 1(b)). Sulfate-alkaline-earth-type thermal waters with temperatures between $50^{\circ} \mathrm{C}$ and $62^{\circ} \mathrm{C}$ are more mineralized and have higher gas contents $\left(\mathrm{CO}_{2}\right.$ and $\left.\mathrm{H}_{2} \mathrm{~S}\right)$. By contrast, the waters of the volcanic aquifer comprise fresh and cold bicarbonate-alkaline-earth waters [37,39, 40].

\section{Methods and Data}

Based on the present knowledge of the Viterbo thermal area, new investigations were planned, including: 1) hydrostratigraphic data acquisition; 2) flow and water level measurements; 3) pumping tests; 4) chemical and isotopic analyses; and 5) meteorological, soil and land use data processing.

The hydrostratigraphy of the area was reconstructed based on available studies and the interpretation of 62 lithologic logs. These logs concern wells and boreholes with depths ranging from tens to hundreds of meters and report information on the stratigraphy, aquifer formations, water level and, in some cases, water temperature.

Flow measurements were conducted in August-October 2008, May-June 2009 and September 2010 for 15 thermal springs, 9 cold springs, 7 flowing thermal wells and 28 stream sections. Measurements with an accuracy of $5 \%$ to $10 \%$ were obtained using tanks or current meters.

The water level, temperature and electrical conductivity in the wells were measured in August-October 2008 and May-June 2009 with a multiparametric probe. For the flowing wells, the water level was determined according to the fluid pressure measured with a manometer. In total, 130 wells with depths of 5 to $150 \mathrm{~m}$ were measured in or near the hydrothermal area.

Pumping test results at five wells that penetrate the shallow volcanic aquifer were acquired from the literature. Two new pumping tests were performed to monitor the temperature and/or electrical conductivity of the pumped water. Six other step-drawdown tests were also conducted for the same aquifer.

Three new pumping tests were also performed on the thermal wells. Two tests were conducted at a constant rate with observation piezometers or springs to monitor the chemical and physical characteristics of the water at each point. A third test was conducted by opening and closing a flowing well and observing the response of a second well.

Water from a total of 52 sources was sampled during a survey conducted in June 2009 and during the pumping tests.

The temperature, $\mathrm{pH}$ and electrical conductivity were measured in the field using portable meters. The alkalinity was determined on-site by means of titration.

Major anions $\left(\mathrm{Cl}^{-}, \mathrm{SO}_{4}^{2-}\right)$, nitrate $\left(\mathrm{NO}_{3}^{-}\right)$and fluoride $\left(\mathrm{F}^{-}\right)$were determined by ion chromatography using a Dionex-DX-120 system. Major cations $\mathrm{Na}^{+}, \mathrm{K}^{+}, \mathrm{Ca}^{2+}$, $\left.\mathrm{Mg}^{2+}\right), \mathrm{Sr}, \mathrm{Li}$ and $\mathrm{Fe}$ liquid were determined by atomic absorption spectrophotometry with a Perkin-Elmer 2100 system. $\mathrm{SiO}_{2}$ was determined with a Secomann S. 500 photocolorimeter. The analytical accuracy of these methods ranges from $2 \%$ to $5 \%$, and the charge balance errors were generally less than $5 \%$.

The $\mathrm{CO}_{2}$ and $\mathrm{H}_{2} \mathrm{~S}$ dissolved gases were determined for 12 thermal springs and wells. The $\mathrm{CO}_{2}$ was determined according to the method reported in Capasso and Inguaggiato (1998) [41] using a gas chromatograph for analyticcal measurements. $\mathrm{H}_{2} \mathrm{~S}$ was stabilized with zinc acetate and determined in the laboratory by means of titration.

Selected environmental isotopes were analyzed in 24 of these samples. Stable isotopes of water, ${ }^{2} \mathrm{H}$ and ${ }^{18} \mathrm{O}$, and ${ }^{18} \mathrm{O}$ and ${ }^{34} \mathrm{~S}$ of dissolved sulfate were determined by mass spectrometry. The standards used were V-SMOV for oxygen and hydrogen and V-CDT for sulfur. ${ }^{18} \mathrm{O}$ of water was determined on $\mathrm{CO}_{2}$ isotopically equilibratum with $\mathrm{H}_{2} \mathrm{O}$ [42], and ${ }^{2} \mathrm{H}$ was determined from $\mathrm{H}_{2}$ produced by the $\mathrm{Zn}$-reduction method. For ${ }^{34} \mathrm{~S}$ analyses, $\mathrm{SO}_{4}$ was prepared using the methods of Yanagisawa and Sakai (1983) [43], and ${ }^{18} \mathrm{O}$ of sulfate was measured from $\mathrm{CO}_{2}$ prepared by graphite reduction of $\mathrm{BaSO}_{4}$. All values are reported by delta notation $(\delta \%)$. The analytical error is estimated to be less than $\pm 1 \%$.

For 15 samples, the tritium concentration was also determined. The samples were distilled, enriched and vac- 
uum-distilled before a liquid scintillation cocktail was added. Analyses were performed using a Perkin-Elmer liquid scintillation counter for twelve 120-min cycles [44]. The results were reported in tritium units (TU).

The air temperature and rainfall data for the area were obtained from the SIMN (Italian hydrographic survey) for the period 1951-1999 [45] and from Regione Lazio for 2000-2010 [46]. The data from the Viterbo meteorological station ( $327 \mathrm{~m}$ asl) were statistically processed to analyze the homogeneity of the data series by applying the cumulative residuals method, and gaps were filled in to complete the series $[47,48]$.

The soil characterization was obtained from the literature [49-51], and the land use information was derived from the Regione Lazio GIS [52].

\section{Results}

\subsection{Hydrostratigraphic Setting}

The surface geology grouped by hydrogeological terms is given in Figure 2(a). The sedimentary substratum of the Pleistocene volcanites, together with the likely faults and fractures, are shown in Figure 2(b), as found in the literature $[9,53-56]$ and in the examined lithologic logs. Representative hydrogeological cross-sections are shown in Figure 3.

The analysis of cross-section and well data highlights a shallow unconfined or leaky aquifer (referred to as the Shallow Aquifer or SA) up to tens of meters thick. The aquifer is contained within the Pleistocene volcanites, which mainly consist of ignimbrites, tuffs and lava flows.

Below the first aquifer, a second confined aquifer (Figure 3) is characterized by thermal waters (referred to as the Thermal Aquifer or TA). This aquifer is intercepted by deeper wells within the volcanites, at the contacts between the volcanites and the flysch units or within the upper portion of the same flysch units, which mainly consist of claystones, marls, marly limestones, sandstones and siliceous limestones.

A low-permeability layer with a thickness of a few meters to tens of meters divides the SA from the TA and is composed of hydrothermally altered pyroclastic deposits or clayey layers of the flysch units.

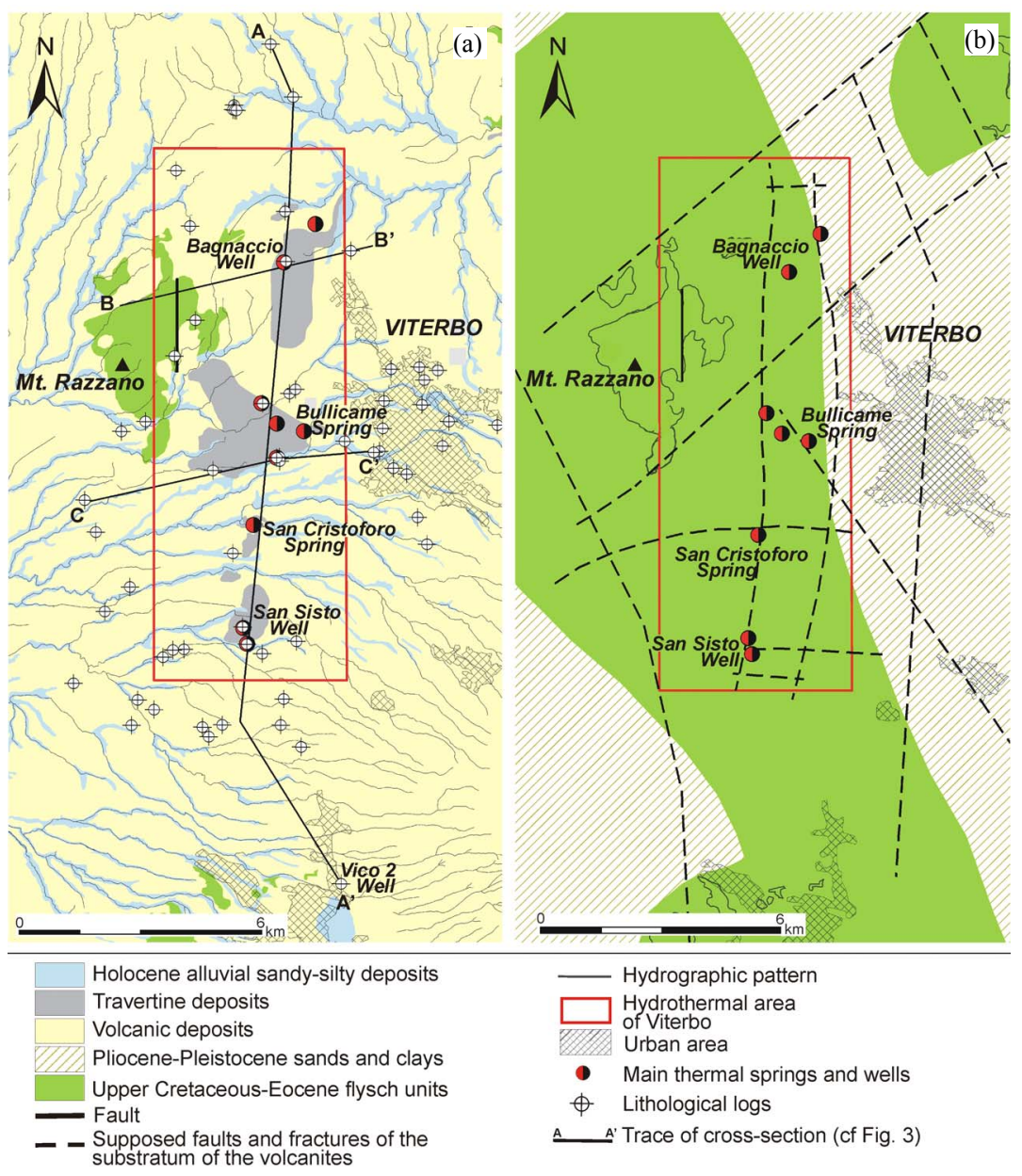

Figure 2. (a) Surface geology of the study area; (b) Sedimentary substratum of the Pleistocene volcanites with the supposed faults and fractures $[9,53-56]$. 


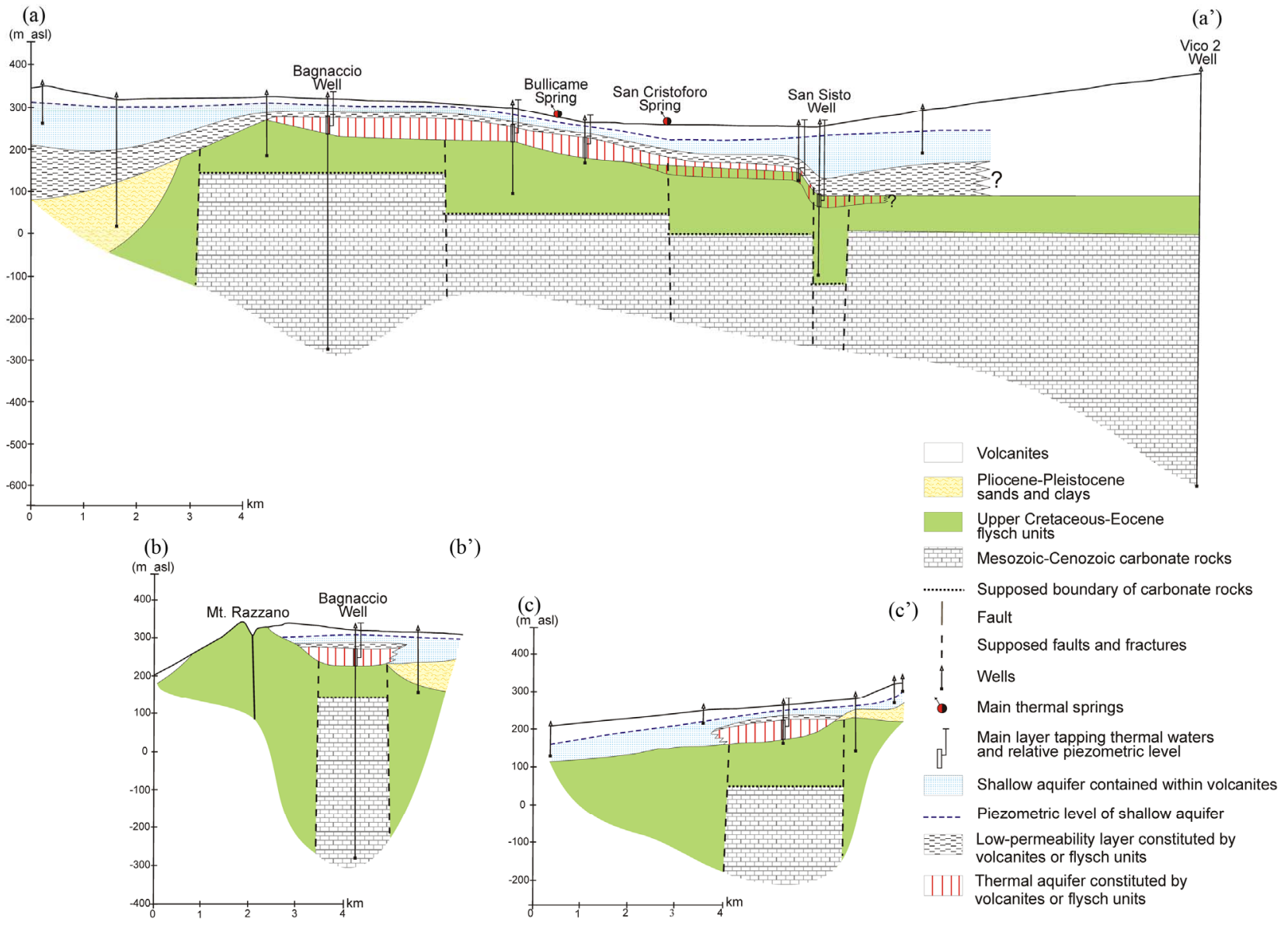

Figure 3. Hydrogeological cross-sections N-S (a-a') and W-E oriented (b-b', c-c'), showing the hydrostratigraphy of the study area.

A third aquifer can be recognized within the deep carbonate rocks, which include limestones, marly limestones, marls, dolomitic limestones, dolostone, and anhydrites. Thermal flow was found in boreholes intercepting this aquifer. In the Bagnaccio Well (Figure 3), the thermal flow was lower than that intercepted in the volcanites and in the flysch units [53,54,57]. In the Vico 2 Well (Figure $3)$, the thermal flow had the same temperature as that found in the volcanites $\left(62^{\circ} \mathrm{C}\right)$ [57]. In Vico 1 Well (V1 in Figure 1(b)), water with a temperature between 50 and $65^{\circ} \mathrm{C}$ was found in the carbonate rocks [57]. In Vetralla 1 Well (VTR1 in Figure 1(b)), a production test at a depth of $1130-1145 \mathrm{~m}$ in the carbonate rocks gave a maximum discharge of approximately $15 \mathrm{~L} / \mathrm{s}$ and a temperature of $61^{\circ} \mathrm{C}[38]$.

In the Vulsini volcanic area, which is tens of kilometers from the study area, the same Mesozoic-Cenozoic carbonate rocks were recognized as the deep reservoir that feeds two deep geothermal wells characterized by $\mathrm{Na}(\mathrm{K})-\mathrm{Cl}$ water with a high temperature $\left(120^{\circ} \mathrm{C}-230^{\circ} \mathrm{C}\right)$ and salinity $(6-12 \mathrm{~g} / \mathrm{L})$ [58-63].
The volcanic basement is uplifted, and the flysch units have relatively reduced thicknesses in the hydrothermal area of Viterbo. The SA overlies thick flysch units to the west and low-permeability Pliocene-Pleistocene units to the east, which are mainly constituted by sands and clays. Deep wells east or west of the uplifted block do not tap thermal flow (Figure 3).

\subsection{Flow and Water Level Measurements}

The location of the flow and water level measurements conducted between 2008 and 2010 is shown in Figure 4. Table 1 summarizes the results of the flow measurements.

Thermal water discharges are grouped into zones (Figure 4(b)), and their average values during 2008-2010 are compared with those from 1983-1984 (Table 1).

The cold water discharge is computed from the springs and gaining streams in the area (Table 1 and Figure 4(a)). One of the springs, Pidocchio Spring, can be related to the basal water table of the SA if the elevation of the spring (238 $\mathrm{m}$ asl) is compared with the piezometric level measured in the neighboring shallow wells; the other springs 


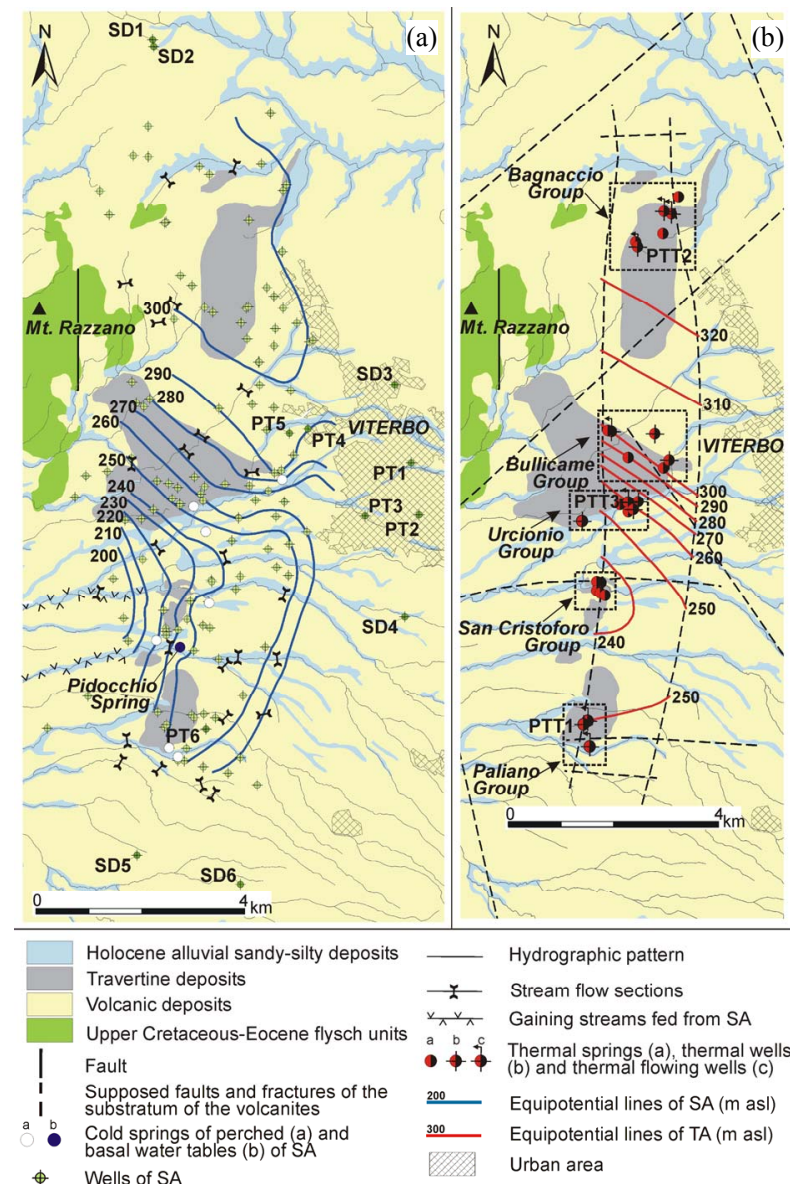

Figure 4. Location of the flow, water level measurements and pumping tests with equipotential maps reconstructed for (a) the shallow aquifer, SA; and (b) Thermal aquifer, TA.

Table 1. Results of flow measurements conducted during 2008-2010 (T: temperature; Q: discharge).

\begin{tabular}{|c|c|c|c|c|}
\hline \multicolumn{5}{|c|}{ Thermal springs and flowing thermal wells } \\
\hline $\begin{array}{l}\text { Group of springs } \\
\text { and wells }\end{array}$ & $\begin{array}{l}\text { Elevation } \\
(\mathrm{m} \cdot \mathrm{asl})\end{array}$ & $\mathrm{T}\left({ }^{\circ} \mathrm{C}\right)$ & $\begin{array}{c}\mathrm{Q}(\mathrm{L} / \mathrm{s}) \\
2008-2010\end{array}$ & $\begin{array}{c}\mathrm{Q}(\mathrm{L} / \mathrm{s}) \\
1983-1984^{\mathrm{a}}\end{array}$ \\
\hline Bagnaccio Group & $310-320$ & $34-62$ & 10.3 & 17.2 \\
\hline Bullicame Group & $284-300$ & $40-61$ & 29.9 & 42.3 \\
\hline Urcionio Group & $260-269$ & $41-55$ & 22.8 & 18.3 \\
\hline S. Cristoforo Group & $225-242$ & $35-54$ & 2.6 & 1.8 \\
\hline Paliano Group & $240-255$ & $54-59$ & 13.2 & 9.0 \\
\hline Total discharge (L/s) & & & 78.8 & 88.6 \\
\hline \multicolumn{5}{|c|}{ Springs and increases of streamflow of the shallow aquifer } \\
\hline Type & \multicolumn{2}{|c|}{ Elevation (m·asl) } & $\mathrm{T}\left({ }^{\circ} \mathrm{C}\right)$ & $\mathrm{Q}(\mathrm{L} / \mathrm{s})$ \\
\hline $\begin{array}{c}\text { Spring of basal } \\
\text { water-table } \\
\text { (Pidocchio Spring) }\end{array}$ & \multicolumn{2}{|r|}{238} & 17 & 12.5 \\
\hline $\begin{array}{l}\text { Springs of perched } \\
\text { water-tables }\end{array}$ & \multicolumn{2}{|c|}{$240-284$} & $16-32$ & 4.0 \\
\hline $\begin{array}{l}\text { Increase of } \\
\text { stream flow }\end{array}$ & \multicolumn{2}{|c|}{$<240$} & & 90.7 \\
\hline Total discharge (L/s) & & & & 107.2 \\
\hline
\end{tabular}

${ }^{a}$ From Camponeschi and Nolasco (1984) [57]. are related to the perched aquifers of the volcanites. A significant flow arising from the discharge from the basal water table of the SA was measured in the streams of the southern zone during the dry season of 2008 (Figure 4(a)).

The first equipotential map of the SA is based on wells containing water below $23^{\circ} \mathrm{C}$. The second map includes wells with temperatures up to $31^{\circ} \mathrm{C}$ (Figure 4(a)) but is not significantly different from the first map. The equipotential map shows a general conformity of the water-table contours with the topography. The hydraulic gradient varies between 0.006 and 0.06 .

A rough potentiometric surface of the TA is given in Figure 4(b). This reconstruction is based on the measurements of the water level or fluid pressure of the deeper wells and the elevation of the springs, which both have water temperatures above $40^{\circ} \mathrm{C}$. The map shows two main directions of flow, one oriented NE-SW and a second oriented SE-NW, that converge toward the western boundary of the hydrothermal area.

By comparing the equipotential maps of the TA and SA, a difference in the hydraulic head between 5 and 20 $\mathrm{m}$ can be estimated. The values for the vertical gradient are between 0.2 and 1 with a thickness of the low-permeability layer up to $40 \mathrm{~m}$.

\subsection{Pumping Tests}

The wells used for the pumping tests on the SA are reported in Figure 4(a). The test results are given in Table 2.

Table 2. Results of pumping tests of shallow and thermal wells.

\begin{tabular}{|c|c|c|c|c|}
\hline \multicolumn{5}{|c|}{ Shallow wells used for pumping tests } \\
\hline Well & $\mathrm{Q}(\mathrm{L} / \mathrm{s})$ & $\mathrm{b}(\mathrm{m})$ & Transmissivity $\left(\mathrm{m}^{2} / \mathrm{s}\right)$ & Storativity \\
\hline PT $1^{\mathrm{a}}$ & 0.35 & 26 & $2.6 \times 10^{-4}$ & $1.2 \times 10^{-3}$ \\
\hline PT $2^{\mathrm{a}}$ & 0.43 & 17 & $1.3 \times 10^{-4}$ & $7.8 \times 10^{-3}$ \\
\hline PT $3^{\mathrm{a}}$ & 1.25 & 34 & $3.0 \times 10^{-3}$ & $7.9 \times 10^{-3}$ \\
\hline $\mathrm{PT} 4^{\mathrm{a}}$ & 14.0 & 14 & $1.1 \times 10^{-2}$ & - \\
\hline PT $5^{\mathrm{a}}$ & 9.7 & 20 & $2.3 \times 10^{-2}$ & $1.8 \times 10^{-3}$ \\
\hline PT 5 & 20 & 20 & $4.5 \times 10^{-2}$ & $6.9 \times 10^{-2}$ \\
\hline PT 6 & 7.7 & 46 & $5.4 \times 10^{-3}$ & $5.9 \times 10^{-3}$ \\
\hline \multicolumn{5}{|c|}{ Shallow wells used for step-drawdown tests } \\
\hline Well & $\mathrm{Q}(\mathrm{L} / \mathrm{s})$ & $\mathrm{b}(\mathrm{m})$ & $\begin{array}{c}\text { Specific capacity } \\
\left(\mathrm{m}^{2} / \mathrm{s}\right)\end{array}$ & $\begin{array}{c}\text { Transmissivity } \\
\left(\mathrm{m}^{2} / \mathrm{s}\right)\end{array}$ \\
\hline SD 1 & 26 & 54 & $2.6 \times 10^{-2}$ & $2.2 \times 10^{-2}$ \\
\hline SD 2 & 25 & 60 & $7.8 \times 10^{-3}$ & $5.2 \times 10^{-3}$ \\
\hline SD 3 & 4 & 40 & $4.0 \times 10^{-3}$ & $2.4 \times 10^{-3}$ \\
\hline SD 4 & 2 & 20 & $1.5 \times 10^{-4}$ & $4.8 \times 10^{-5}$ \\
\hline SD 5 & 2 & 29 & $3.3 \times 10^{-4}$ & $1.2 \times 10^{-4}$ \\
\hline SD 6 & 5 & 21 & $5.0 \times 10^{-4}$ & $2.0 \times 10^{-4}$ \\
\hline \multicolumn{5}{|c|}{ Thermal wells used for production tests } \\
\hline Well & $\mathrm{Q}(\mathrm{L} / \mathrm{s})$ & $\mathrm{b}(\mathrm{m})$ & Transmissivity $\left(\mathrm{m}^{2} / \mathrm{s}\right)$ & Storativity \\
\hline PTT 1 & 386 & 35 & $8.0 \times 10^{-4}$ & $2.0 \times 10^{-4}$ \\
\hline P111 & 38.6 & 35 & $1.0 \times 10^{-3}$ & $3.6 \times 10^{-4}$ \\
\hline PTT 2 & 46.4 & 55 & $\begin{array}{l}1.4 \times 10^{-2} \\
2.8 \times 10^{-2}\end{array}$ & 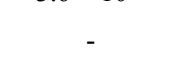 \\
\hline PTT 3 & 21.5 & 30 & $3.9 \times 10^{-3}$ & - \\
\hline
\end{tabular}

${ }^{\text {a }}$ from Piscopo et al. 2006 [37]; Q: discharge; b: saturated thickness. 
Five pumping tests (PT1-PT6 in Table 2) were acquired from Piscopo et al. (2006) [37]. The new test conducted on PT5 reveals an increase in temperature from $16.0^{\circ} \mathrm{C}$ to $16.8^{\circ} \mathrm{C}$ after 25 hours of pumping and hydraulic parameters comparable to those previously determined. The test conducted on PT6 did not show an increase in temperature or electrical conductivity during pumping.

Six other step-drawdown tests were conducted on the SA (SD1-SD6 in Table 2), and the specific capacity was determined. Using the relationship between transmissivity and specific capacity found for the Cimino-Vico system [34], transmissivity was determined (Table 2).

The tests conducted on wells that intercept thermal waters (PTT1, PTT2 and PTT3) are shown in Figure 4(b), and the results are given in Table 2.

The PTT1 test was conducted at a constant flow for 68 hours on a 125 -m-deep well that penetrates fractured flysch formations. The monitored wells and springs are shown in Figure 5(a). The piezometer at the SA and the thermal springs of the San Cristoforo Group did not show significant variations. The San Sisto Well, which is a thermal flowing well, dried up during the pumping and flowed again after the shutdown of the well (Figure 5(b)). The electrical conductivity and temperature of the thermal water were constant in the pumped and observation wells (Figure 5(c)). Other chemical and isotopic parameters did not exhibit significant variations during the pumping period.

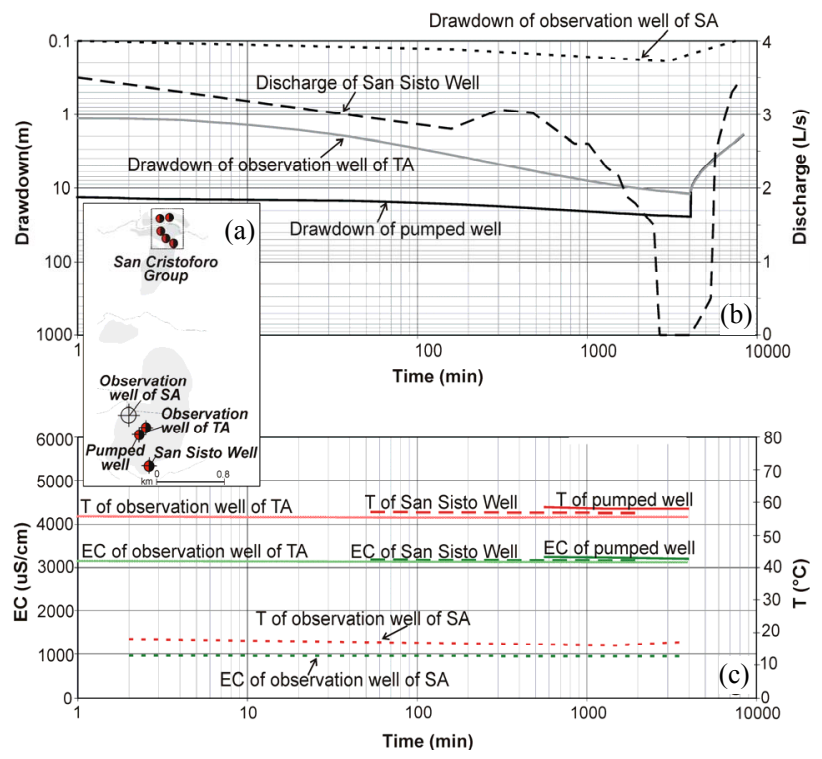

Figure 5. Results of the pumping test conducted on PTT1 well: (a) Location of monitored wells and springs; (b) Trend of drawdown in the tested well and in two observation piezometers, and of discharge of the San Sisto Well; (c) Trend of temperature (T) and electrical conductivity of waters (EC) of the monitored wells.
The best match of drawdown data from the observation well of the TA was obtained at a transmissivity of 8 $\times 10^{-4}$ to $1 \times 10^{-3} \mathrm{~m}^{2} / \mathrm{s}$ and a storativity of 2 to $4 \times 10^{-4}$ by applying the double porosity model.

The PTT2 test was conducted on the Bagnaccio Well, which was drilled during geothermal exploration during the 1950s [53,54]. The Bagnaccio Well was originally $600 \mathrm{~m}$ deep, and it was recently (2008) renovated to a depth of $100 \mathrm{~m}$ to better capture the thermal water from the volcanites. The flowing well was tested for 48 hours at a constant rate by measuring the fluid pressure (results in Figure 6). When the flowing well was closed, the pressure immediately returned to its initial value. During the test period, the physical-chemical characteristics of the water and the other monitored chemical and isotopic parameters did not change. Among the wells and springs monitored during the pumping, only the Bagnaccio Spring (78 $\mathrm{m}$ from the well) showed a significant variation (Figure 6).

An approximate transmissivity of $2.8 \times 10^{-2} \mathrm{~m}^{2} / \mathrm{s}$ was estimated by applying the Cooper-Jacob method to the drawdown data measured in the production well. The distance-drawdown method, which was applied considering the Bagnaccio Spring as a piezometer, permitted to determine transmissivity values between $1.4 \times 10^{-2}$ and $2.3 \times 10^{-2} \mathrm{~m}^{2} / \mathrm{s}$ (Table 2).

A third test on the thermal aquifer was conducted in the central zone (PTT3 test) by closing a well that normally flows six days a week at a constant rate of $21.5 \mathrm{~L} / \mathrm{s}$. Recovery was observed at a second well $129 \mathrm{~m}$ away. The two wells are 42 and $93 \mathrm{~m}$ deep and capture thermal water from the volcanites. The transmissivity was estimated to be $3.9 \times 10^{-3} \mathrm{~m}^{2} / \mathrm{s}$ when considering the residual

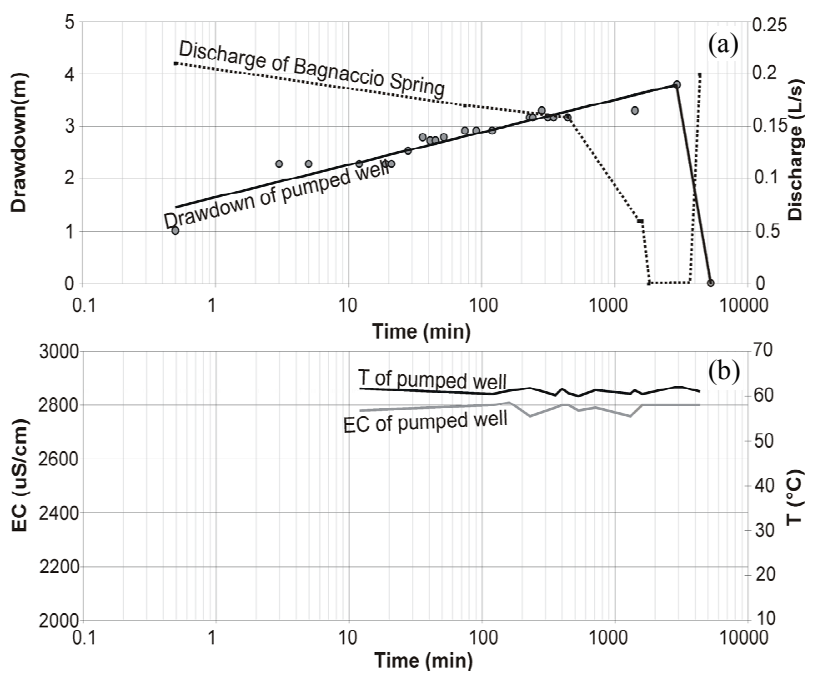

Figure 6. Results of the pumping test conducted on PTT2 well: (a) Trend of drawdown in the tested well and of discharge of the Bagnaccio Spring; (b) Trend of temperature (T) and electrical conductivity of waters (EC) of the tested well. 
drawdown in the second well, the times since the initiation and termination of pumping, and the discharge of the flowing well.

\subsection{General Chemistry}

The main chemical constituents of all of the samples are provided in Table 3. The samples were categorized as one of the following: thermal water (spring, $t s$, and well, $t w)$ from TA; spring $(s)$ and well $(w)$ of the SA; and stream waters $(s t)$. The location of the sampled water is shown in Figure 7.

According to the physical-chemical characteristics and the relative abundance of major cations and anions, the thermal waters (also including the waters of Bagnaccio Pond, 7 in Table 3 and Figure 7, which are influenced by the flow of the SA) exhibit a homogenous hydrochemical facies. They are calcium-sulfate waters (Figure 8) that are characterized by a temperature (T) of $40^{\circ} \mathrm{C}$ to $62^{\circ} \mathrm{C}$, a pH less than 7, and a specific electrical conductivity (EC) between 2800 and $3600 \mu \mathrm{S} / \mathrm{cm}$.

Wells and springs fed from the SA show a more heterogeneous hydrochemical facies and range from calciumalkaline-bicarbonate to calcium-sulfate waters (Figure 8), with a $\mathrm{T}$ of $16^{\circ} \mathrm{C}$ to $31^{\circ} \mathrm{C}, \mathrm{pH}$ up to 8 , and $\mathrm{EC}$ of 300 to $2900 \mu \mathrm{S} / \mathrm{cm}$. The two sampled streams have opposite geochemical profiles: one is recharged by the SA (i.e., 15 in Table 3 and Figure 7), whereas the other also by the TA (i.e., 32 in Table 3 and Figure 7).

Among the minor and trace constituents, Li (generally between 0.01 and $0.1 \mathrm{mg} / \mathrm{L}$ ) and $\mathrm{Fe}$ (generally between 0.01 and $0.2 \mathrm{mg} / \mathrm{L}$ ) are present at very low concentrations. The $\mathrm{NO}_{3}^{-}$concentration is lower in thermal waters (generally less than $5 \mathrm{mg} / \mathrm{L}$ ) than in the waters of the SA (up to $100 \mathrm{mg} / \mathrm{L}$, relative to the depth of the water level below the ground). The $\mathrm{SiO}_{2}$ concentration varies between 40 and $55 \mathrm{mg} / \mathrm{L}$ for thermal waters and is generally lower for the other waters. The strontium concentration is higher in thermal waters, as is the fluoride concentration (Table 3).

The Pearson correlation matrix of the entire dataset shows a strong correlation among $\mathrm{EC}, \mathrm{T}, \mathrm{Mg}^{2+}, \mathrm{SO}_{4}^{2-}$, $\mathrm{Sr}$, and $\mathrm{HCO}_{3}^{-}(\mathrm{R}>0.8)$. The plot of $\mathrm{Sr}$ versus the sulfate concentration in Figure 9 highlights one of these correlaons.

The concentrations of dissolved $\mathrm{CO}_{2}$ and $\mathrm{H}_{2} \mathrm{~S}$ gas in the 12 thermal waters $(4,8,9,14,16,18,20,30,34,44$, 45, 48 in Figure 7) vary between 300 and $600 \mathrm{mg} / \mathrm{L}$ and 7 and $30 \mathrm{mg} / \mathrm{L}$, respectively.

The highest values were found in the deeper wells that had proper screening, casing and sealing.

These results agree with the previous hydrochemical characterization $[37,40]$ and further highlight that the geochemical profile of the waters of the SA appears to be influenced by mixing with thermal waters (Figures 8 and 9). To analyze this point thoroughly, sulfate content was considered as one of the constituents that discriminates the different waters (see also the stable isotope analysis). The following relationship, which has been used in the literature to determine the components of stream flow [64], was applied:

$$
C i \cdot Q i=C t \cdot Q t+C c \cdot Q c
$$

where

$\mathrm{C} i$ is the sulfate concentration in water sampled from the SA;

$C t$ is the average sulfate concentration of the thermal waters $(1193 \mathrm{mg} / \mathrm{L})$ and is one of the end members;

$C c$ is the sulfate concentration in Pidocchio Spring (39 in Table 3 and Figure 7), which represents the other end member $(19 \mathrm{mg} / \mathrm{L})$, i.e., cold water from the SA that is not influenced by the thermal flow;

$Q i$ is the total flow rate of the SA;

$Q t$ is the component of the flow rate of thermal waters in the SA; and

$Q c$ is the component of the flow rate of cold waters in the SA.

Considering that $Q i=Q t+Q c$, Equation (1) can be rewritten as

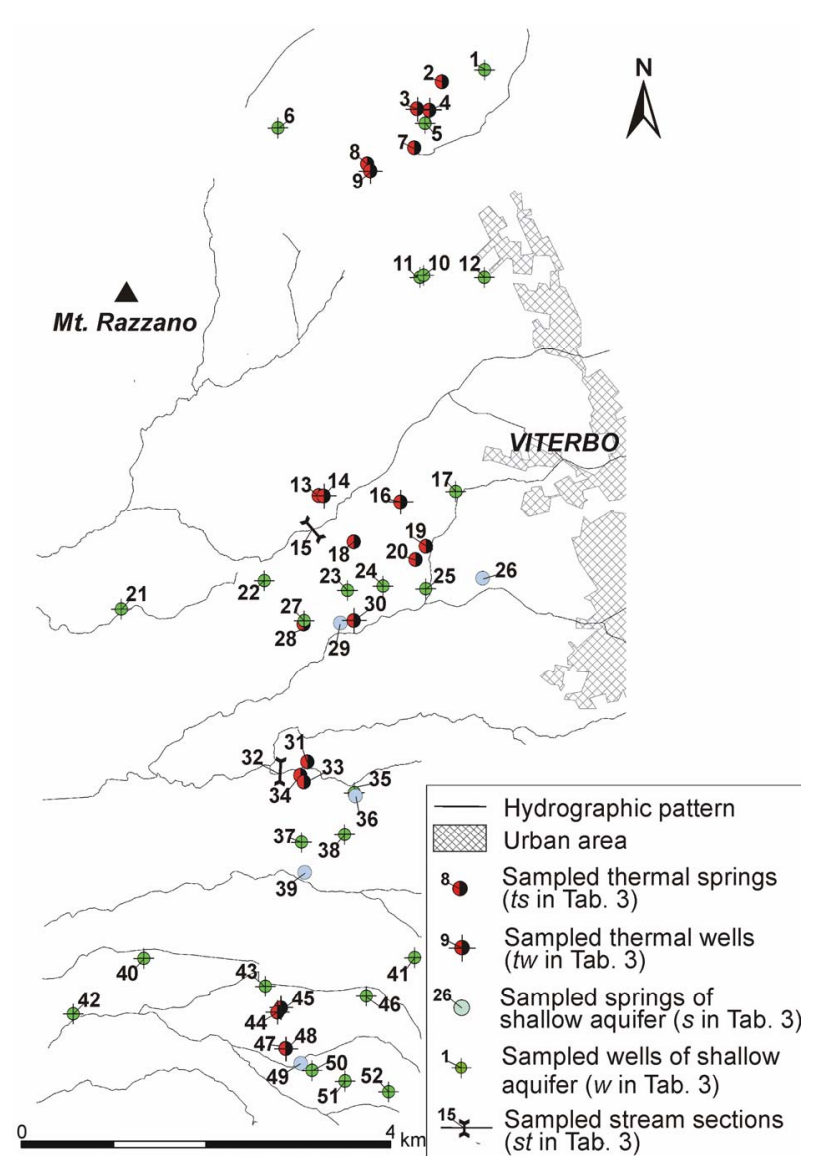

Figure 7. Location of sampled waters (IDs in Table 3). 
Table 3. Main chemical constituents of sampled waters (June 2009).

\begin{tabular}{|c|c|c|c|c|c|c|c|c|c|c|c|c|c|c|}
\hline ID & Type & $\mathrm{T}\left({ }^{\circ} \mathrm{C}\right)$ & $\mathrm{pH}$ & $\begin{array}{c}\text { EC } \\
(\mu \mathrm{S} / \mathrm{cm})\end{array}$ & $\begin{array}{c}\mathrm{Na}^{+} \\
(\mathrm{mg} / \mathrm{L})\end{array}$ & $\begin{array}{c}\mathrm{K}^{+} \\
(\mathrm{mg} / \mathrm{L})\end{array}$ & $\begin{array}{c}\mathrm{Ca}^{2+} \\
(\mathrm{mg} / \mathrm{L})\end{array}$ & $\begin{array}{l}\mathrm{Mg}^{2+} \\
(\mathrm{mg} / \mathrm{L})\end{array}$ & $\begin{array}{c}\mathrm{Cl}^{-} \\
(\mathrm{mg} / \mathrm{L})\end{array}$ & $\begin{array}{l}\mathrm{HCO}_{3}^{-} \\
(\mathrm{mg} / \mathrm{L})\end{array}$ & $\begin{array}{c}\mathrm{SO}_{4}^{2-} \\
(\mathrm{mg} / \mathrm{L})\end{array}$ & $\begin{array}{c}\mathrm{SiO}_{2} \\
(\mathrm{mg} / \mathrm{L})\end{array}$ & $\begin{array}{c}\mathrm{Sr} \\
(\mathrm{mg} / \mathrm{L})\end{array}$ & $\begin{array}{c}\mathrm{F}^{-} \\
(\mathrm{mg} / \mathrm{L})\end{array}$ \\
\hline 1 & $w$ & 24.0 & 7.31 & 1450 & 29 & 19 & 205 & 78 & 21.8 & 463 & 465 & 41.0 & 2.6 & 1.9 \\
\hline $2(\mathrm{Ba})$ & $t s$ & 50.0 & 6.70 & 3011 & 36 & 29 & 515 & 145 & 13.0 & 976 & 1100 & 43.3 & 11.4 & 4.0 \\
\hline $3(\mathrm{Ba})$ & $t w$ & 62.4 & 6.85 & 3290 & 49 & 30 & 504 & 150 & 16.2 & 1055 & 1155 & 47.5 & 11.6 & 3.9 \\
\hline $4(\mathrm{Ba})$ & $t w$ & 59.6 & 6.57 & 3300 & 36 & 29 & 508 & 145 & 17.8 & 1094 & 1140 & 47.3 & 11.4 & 4.2 \\
\hline 5 & $w$ & 17.0 & 7.40 & 1630 & 27 & 20 & 230 & 60 & 27.2 & 610 & 545 & 39.6 & 4.7 & 1.9 \\
\hline 6 & $w$ & 18.6 & 7.72 & 738 & 44 & 35 & 81 & 24 & 78.3 & 249 & 58 & 37.5 & 0.47 & 0.5 \\
\hline $7(\mathrm{Ba})$ & $t s$ & 33.6 & 6.20 & 3360 & 44 & 30 & 542 & 150 & 18.2 & 945 & 1300 & 40.3 & 12.2 & 3.2 \\
\hline $8(\mathrm{Ba})$ & $t s$ & 62.3 & 6.30 & 3170 & 35 & 28 & 487 & 150 & 14.4 & 985 & 1106 & 18.2 & 11.7 & 3.6 \\
\hline $9(\mathrm{Ba})$ & $t w$ & 61.7 & 6.32 & 2780 & 33 & 26 & 527 & 165 & 15.4 & - & 1270 & 40.3 & 11.3 & 4.7 \\
\hline 10 & $w$ & 29.4 & 6.10 & 2920 & 38. & 28 & 468 & 115 & 23.8 & 1073 & 1023 & 29.6 & 9.7 & 1.5 \\
\hline 11 & $w$ & 25.2 & 6.20 & 2890 & 41 & 28 & 471 & 115 & 21.0 & 1061 & 956 & 40.0 & 9.9 & 1.3 \\
\hline 12 & $w$ & 17.0 & 7.80 & 535 & 41 & 16 & 43 & 12 & 19.0 & 189 & 53 & 39.3 & 2.2 & 3.6 \\
\hline $13(\mathrm{Bu})$ & $t s$ & 58.9 & 6.41 & 3230 & 34 & 29 & 500 & 141 & 15.2 & 1005 & 1115 & 45.0 & 12.1 & 4.2 \\
\hline $14(\mathrm{Bu})$ & $t w$ & 60.6 & 6.44 & 3200 & 34. & 30 & 502 & 140 & 15.6 & 1018 & 1100 & 49.1 & 11.7 & 4.3 \\
\hline 15 & $s t$ & 19.9 & 8.07 & 1255 & 44 & 21 & 168 & 40 & 49.4 & 457 & 282 & 39.4 & 2.7 & 1.9 \\
\hline $16(\mathrm{Bu})$ & $t w$ & 54.5 & 6.43 & 2900 & 34 & 31 & 456 & 115 & 17.6 & 1030 & 976 & 47.1 & 10.4 & 4.0 \\
\hline 17 & $w$ & 21.6 & 7.80 & 747 & 23 & 14 & 126 & 11 & 20.2 & 305 & 129 & 38.9 & 2.9 & 3.8 \\
\hline $18(\mathrm{Bu})$ & $t s$ & 57.8 & 6.40 & 3000 & 34 & 33 & 510 & 120 & 15.1 & 1067 & 986 & 48.2 & 11.1 & 3.3 \\
\hline $19(\mathrm{Bu})$ & $t w$ & 40.0 & 6.37 & 2770 & 34 & 27 & 496 & 109 & 17.0 & 976 & 946 & 45.2 & 9.5 & 2.6 \\
\hline $20(\mathrm{Bu})$ & $t s$ & 54.8 & 6.27 & 2990 & 35 & 30 & 500 & 115 & 12.3 & 1006 & 1091 & 53.6 & 11.1 & 4.0 \\
\hline 21 & $w$ & 21.3 & 7.71 & 756 & 46 & 26 & 73 & 14 & 21.6 & 177 & 141 & 40.2 & 0.60 & 4.0 \\
\hline 22 & $w$ & 21.6 & 6.93 & 1950 & 18 & 10 & 318 & 59 & 15.6 & 601 & 548 & 31.1 & 4.2 & 3.1 \\
\hline 23 & $w$ & 30.5 & 6.63 & 2880 & 30 & 24 & 507 & 112 & 17.0 & 1036 & 971 & 38.4 & 10.7 & 5.2 \\
\hline 24 & $w$ & 24.7 & 7.47 & 1697 & 27 & 34 & 225 & 110 & 14.0 & 378 & 650 & 39.4 & 6.9 & 2.4 \\
\hline 25 & $w$ & 20.0 & 7.40 & 1580 & 32 & 25 & 205 & 75 & 23.2 & 451 & 513 & 40.3 & 5.2 & 2.2 \\
\hline 26 & $s$ & 19.6 & 6.80 & 725 & 35 & 34 & 71 & 18 & 12.7 & 378 & 68 & 41.3 & 0.27 & 1.1 \\
\hline 27 & $w$ & 29.6 & 6.64 & 2480 & 38 & 16 & 465 & 55 & 48.0 & 754 & 912 & 43.3 & 5.6 & 3.6 \\
\hline 28 (Ur) & $t w$ & 41.5 & 6.29 & 3490 & 67 & 28 & 588 & 140 & 20.4 & 1125 & 1299 & 41.3 & 12.2 & 4.4 \\
\hline 29 & $s$ & 31.4 & 6.63 & 2040 & 50 & 20 & 336 & 83 & 27.8 & 724 & 704 & 22.3 & 5.6 & 1.8 \\
\hline 30 (Ur) & $t w$ & 52.5 & 6.37 & 3030 & 46 & 26 & 504 & 125 & 16.4 & 1021 & 1111 & 18.2 & 11.7 & 2.6 \\
\hline $31(\mathrm{Sc})$ & $t s$ & 53.6 & 6.40 & 3570 & 34 & 24 & 635 & 165 & 19.0 & 1066 & 1400 & 40.9 & 13.9 & 5.2 \\
\hline 32 & $s t$ & 27.0 & 7.32 & 1930 & 34 & 22 & 302 & 72 & 21.4 & 549 & 769 & 38.9 & 5.5 & 3.2 \\
\hline $33(\mathrm{Sc})$ & $t s$ & 52.5 & 6.20 & 3520 & 31 & 26 & 618 & 150 & 15.6 & 1069 & 1401 & 51.3 & 13.3 & 3.6 \\
\hline $34(\mathrm{Sc})$ & $t s$ & 43.1 & 6.75 & 3560 & 30 & 26 & 584 & 150 & 15.0 & 1024 & 1346 & 44.2 & 13.7 & 3.1 \\
\hline 35 & $w$ & 21.1 & 7.45 & 393 & 23 & 21 & 43 & 10 & 28.2 & 140 & 42 & 36.6 & 0.34 & 1.8 \\
\hline 36 & $s$ & 16.0 & 7.77 & 490 & 28 & 10 & 36 & 11 & 29.1 & 116 & 46 & 39.5 & 0.54 & 0.5 \\
\hline 37 & w & 25.0 & 8.37 & 350 & 17 & 18 & 27 & 8 & 15.6 & 132 & 18 & 34.5 & 0.17 & 0.8 \\
\hline 38 & $w$ & 21.3 & 7.80 & 532 & 25 & 20 & 46 & 11 & 42.7 & 52 & 57 & 37.6 & 0.38 & 1.1 \\
\hline 39 & $s$ & 17.0 & 7.86 & 327 & 25 & 22 & 15 & 8 & 23.1 & 101 & 19 & 31.3 & 0.17 & 0.8 \\
\hline 40 & $w$ & 20.8 & 6.64 & 1330 & 40 & 16 & 205 & 41 & 35.7 & 483 & 342 & 40.6 & 2.8 & 4.2 \\
\hline 41 & $w$ & 21.0 & 7.66 & 356 & 24 & 19 & 27 & 6 & 25.7 & 97 & 26 & 33.6 & 0.15 & 2.4 \\
\hline 42 & $w$ & 20.5 & 6.55 & 2360 & 27 & 24 & 376 & 90 & 21.0 & 729 & 952 & 42.3 & 8.0 & 4.0 \\
\hline 43 & $w$ & 20.2 & 7.88 & 880 & 9.3 & 4.6 & 157 & 10 & 12.0 & 354 & 69 & 42.0 & 1.3 & 1.7 \\
\hline $44(\mathrm{~Pa})$ & $t w$ & 59.5 & 6.42 & 3540 & 43 & 26 & 637 & 155 & 23.2 & 1055 & 1405 & 39.8 & 13.2 & 3.4 \\
\hline $45(\mathrm{~Pa})$ & $t w$ & 58.5 & - & 3230 & 32 & 26 & 632 & 170 & 19.6 & - & 1300 & 44.0 & 13.2 & 3.2 \\
\hline 46 & $w$ & 25.0 & 6.78 & 930 & 25 & 18 & 158 & 19 & 21.6 & 418 & 140 & 37.5 & 2.0 & 3.0 \\
\hline 47 & $s$ & 24.5 & 6.61 & 713 & 26 & 18 & 91 & 14 & 22.0 & 201 & 134 & 36.6 & 0.81 & 2.6 \\
\hline $48(\mathrm{~Pa})$ & $t w$ & 58.2 & 6.39 & 3510 & 47 & 26 & 617 & 137 & 16.0 & 1069 & 1311 & 46.5 & 13.1 & 4.5 \\
\hline 49 & $s$ & 19.2 & 7.35 & 328 & 22 & 22 & 28 & 6 & 20.6 & 104 & 26 & 32.4 & 0.14 & 2.2 \\
\hline 50 & $w$ & 23.0 & 7.37 & 332 & 26 & 22 & 30 & 6 & 23.0 & 94 & 31 & 30.6 & 0.13 & 2.3 \\
\hline 51 & $w$ & 21.2 & 7.70 & 368 & 27 & 21 & 23 & 5 & 24.2 & 91 & 51 & 31.0 & 0.11 & 3.2 \\
\hline 52 & $w$ & 20.2 & 7.60 & 367 & 28 & 20 & 17 & 6 & 25.4 & 90 & 33 & 37.0 & 0.13 & 2.9 \\
\hline
\end{tabular}

Ba: Bagnaccio Group; Bu: Bullicame Group; Ur: Urcionio Group; Sc: San Cristoforo Group; Pa: Paliano Group; $t s$ : thermal spring; $t w$ : thermal well; $s$ : spring of the shallow aquifer; $w$ : well of the shallow aquifer; st: stream section. 


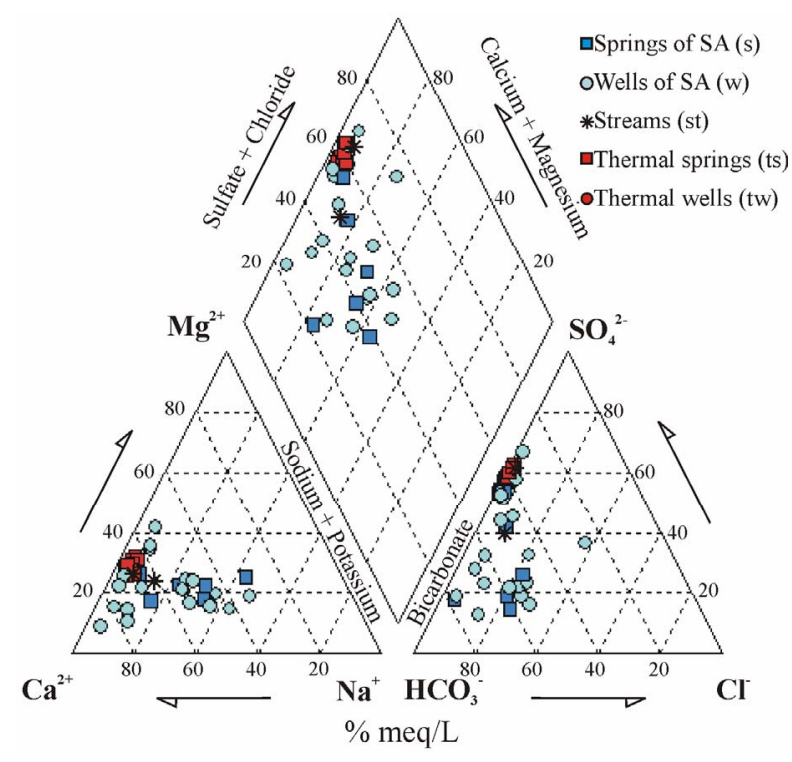

Figure 8. Piper diagram of sampled waters.

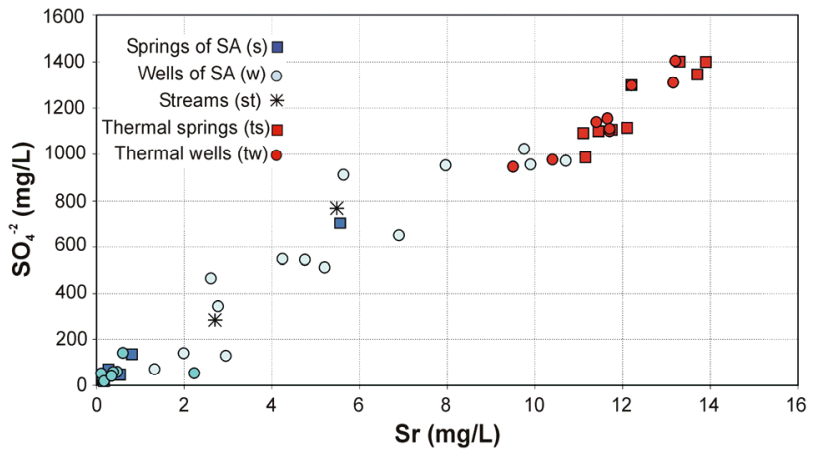

Figure 9. Plot of strontium versus sulfate contents of sampled waters.

$$
\frac{Q t}{Q i}=\frac{C i-C c}{C t-C c}
$$

The ratio $Q t / Q i$ permits us to determine the fraction of thermal water in the groundwater of the SA. As reported in Figure 10(a), $Q t / Q i$ is between 0.1 and 0.5 in the central and northern zones of the Viterbo hydrothermal area and between 0.1 and 0.6 in the western zone beyond the boundary of the hydrothermal area. The same distribution of the $Q t / Q i$ ratio is found when strontium is used as an indicator of the mixing between the thermal waters and cold waters of the SA (Figure 10(b)).

\subsection{Stable Isotopes and Tritium}

The stable isotopes of water $\left(\delta^{18} \mathrm{O}\right.$ and $\left.\delta^{2} \mathrm{H}\right)$, which were determined for thermal waters $(2,3,4,8,9,14,16,18$, 19, 20, 30, 34, 44, 45, 48 in Figure 7), selected wells (6, 21, 23, 41 in Figure 7) and springs of the SA (26, 29, 39 in Figure 7) and two stream waters (15, 32 in Figure 7), are plotted in Figure 11. In the same graph, the global
[65] and central-Italy meteoric water lines [66] and the isotopic contents of Vico Lake [37] are reported. All of the waters exhibit $\delta^{18} \mathrm{O}$ and $\delta^{2} \mathrm{H}$ values in a limited range ( $-5.6 \%$ to $-7.2 \%$ and $-34 \%$ o to $-44 \%$, respectively) and fall on the meteoric water lines, as determined by previous studies [37]. The waters with lower $\delta^{18} \mathrm{O}$ values are from the TA and the basal water table of the SA. If the available vertical isotopic gradients for the western side of the Apennine Chain [66] are considered, then the elevation of the recharge area of the sampled waters ranges between 330 and $1270 \mathrm{~m} \cdot$ asl. When only the waters that are more enriched in $\delta^{18} \mathrm{O}$, i.e., mainly those of the perched aquifers of the SA, are considered, the elevation is less than $470 \mathrm{~m} \cdot a \mathrm{sl}$.

The results for the stable isotopes of dissolved sulfate $\left(\delta^{34} \mathrm{~S}_{\mathrm{SO} 4}\right.$ and $\left.\delta^{18} \mathrm{O}_{\mathrm{SO} 4}\right)$ are plotted in Figure 12, which was modified from Clark and Fritz (1997) [67]. For the thermal waters, the $\delta^{34} \mathrm{~S}_{\mathrm{SO} 4}$ values vary from $11.4 \%$ to $16.8 \%$, and the $\delta^{18} \mathrm{O}_{\mathrm{SO} 4}$ values vary from $11.3 \%$ and $14.2 \%$, with generally lower values for the SA and stream waters. According to the diagram of Clark and Fritz (1997) [67], the thermal waters plot within the Devonian to lower Triassic rectangle, in contrast to the SA and stream waters, which seem to be related to the atmospheric content or mixing with the two previous components. The Mesozoic-Cenozoic carbonate rocks, which constitute the deep substratum of the area under investigation, include Triassic anhydrites.

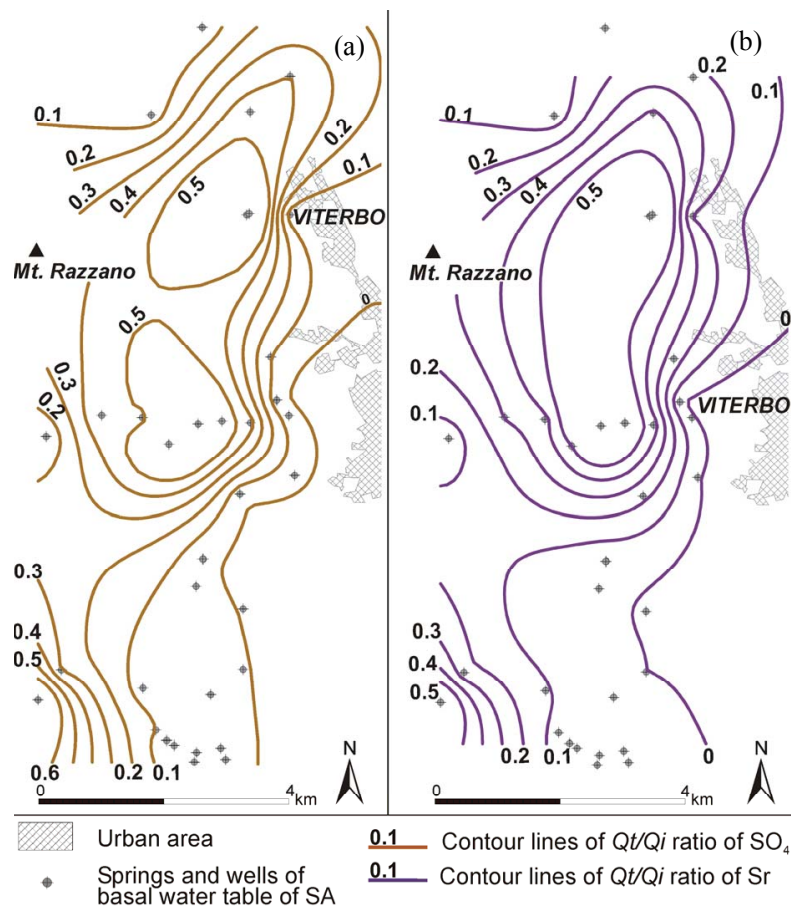

Figure 10. Map of the ratio $Q t / Q i$ which represents the fraction of thermal water $(Q t)$ in the groundwater of the SA (Qi), using (a) sulfate concentration and (b) strontium concentration. 


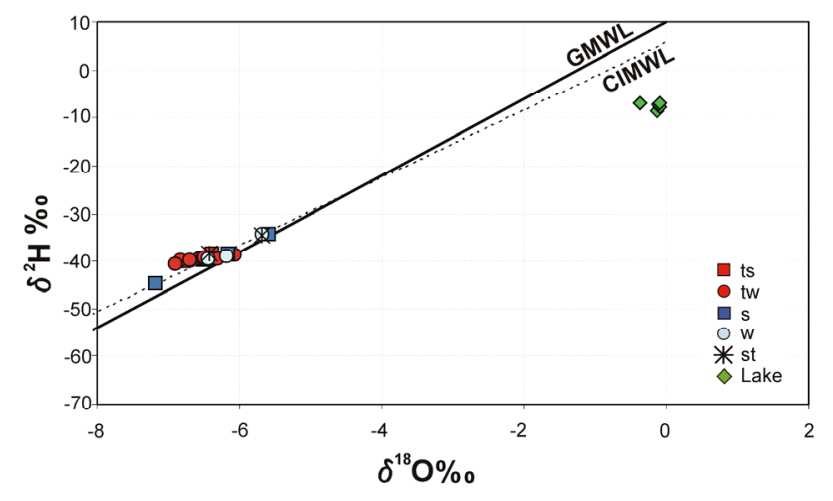

Figure 11. $\delta^{18} \mathrm{O}$ versus $\delta^{2} \mathrm{H}$ in thermal waters ( $t s$ and $t w$ ), some wells ( $w$ ) and springs (s) of SA and stream waters (st), compared with isotopic contents of waters of Vico Lake [37]. The global meteoric (GMWL) and central Italy meteoric water lines (CIMWL) are also shown.

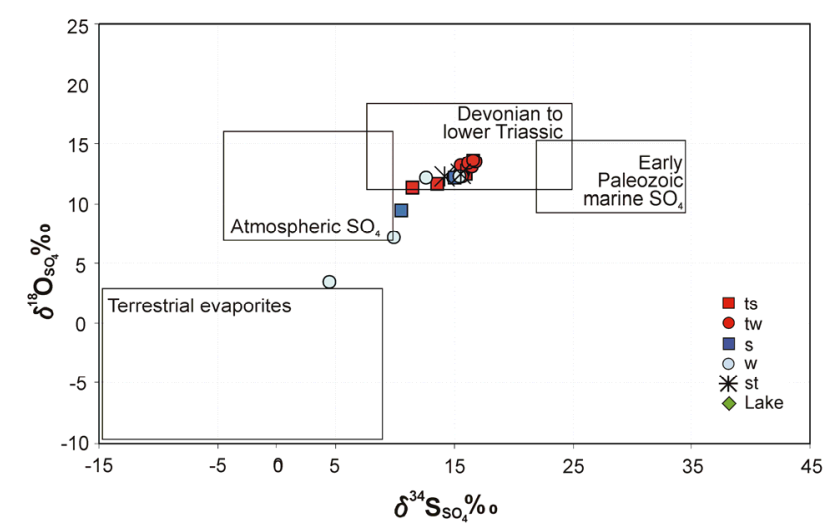

Figure 12. $\delta^{34} \mathrm{~S}_{\mathrm{SO} 4}$ versus $\delta^{18} \mathrm{O}_{\mathrm{SO} 4}$ in dissolved sulfate of thermal waters ( $t s$ and $t w$ ), some wells ( $w$ ) and springs (s) of SA and stream waters (st) (fields from Clark and Fritz, 1997 [67]).

As can be seen from the plot of Figure 12, some SA samples fall in the Devonian to lower Triassic rectangle, which again confirms the mixing with thermal waters.

Of the samples, 15 were analyzed for tritium, of which 12 were from thermal waters $(2,4,8,9,14,16,18,20$, 30, 34, 45, 48 in Figure 7) and 3 were from cold waters $(6,21,41$ in Figure 7). The tritium concentrations varied from 2 to $11 \mathrm{TU}$, which suggests a recent component recharge of waters, i.e., post-1952 [67]. The thermal waters had lower tritium concentrations ( 2 to $5 \mathrm{TU}$ ), whereas samples from wells exclusively intercepting the SA had higher concentrations ( 8 to $11 \mathrm{TU}$ ). If the radioactive half-life for tritium is considered and the same isotopic content of rainwater recharging is assumed for both thermal and cold waters, then there is a 14-year-difference in the residence time between the two types of waters.

\subsection{Soil-Water Budget}

The soil-water budget was estimated with reference to a surface area of approximately $38 \mathrm{~km}^{2}$, including the strip where thermal waters flow out.

The mean annual values of precipitation and temperature for 1989 to 2010 were calculated by processing the meteorological data recorded in Viterbo. The homogeneity of the datasets was evaluated, and missing data were reconstructed on a monthly basis $(2 \%$ of the precipitation data and $0.25 \%$ of the temperature data were missing). The mean annual values for precipitation and temperature are $772 \mathrm{~mm}$ and $15.7^{\circ} \mathrm{C}$, respectively.

Based on the mean monthly rainfall and temperature data, a potential evapotranspiration of $841 \mathrm{~mm} / \mathrm{y}$ was calculated using the Thornthwaite empirical formula [68]. The actual evapotranspiration was also determined by the Thornthwaite-Mather method [69] by considering the soil texture, field capacity, permanent wilting point and land cover for the different zones in the area. The resulting total available water-holding capacity varies between 80 and $160 \mathrm{~mm}$; therefore, the actual evapotranspiration varies between 525 and $605 \mathrm{~mm} / \mathrm{y}$.

The mean annual actual evapotranspiration is $575 \mathrm{~mm}$ for the strip where thermal waters flow out (surface area of $19.66 \mathrm{~km}^{2}$ ), and the difference between the mean annual precipitation and actual evapotranspiration is 197 $\mathrm{mm}$. For the northern and central zones of Figure $\mathbf{1 0}$ with $Q t / Q i$ between 0.1 and 0.5 (surface area of $18.79 \mathrm{~km}^{2}$ ), the mean annual actual evapotranspiration is $581 \mathrm{~mm}$, and the difference between the mean annual precipitation and actual evapotranspiration is $191 \mathrm{~mm}$.

\section{Discussion}

A refinement of the conceptual model and a groundwater resource estimation of the Viterbo thermal area can be derived from the combination of hydrogeological and hydrochemical data.

The hydrogeological interpretation of the stratigraphy enables the characterization of the upper $100-200 \mathrm{~m}$ of the two main aquifers. The shallow aquifer (SA) consists of Pleistocene volcanites and covers the entire study area; the deeper aquifer (TA) is characterized by thermal waters. Within the study area, the two aquifers are generally separated by a low-permeability layer of volcanites or flysch units. At greater depths, a thick low-permeability layer consisting of flysch units is locally fractured and faulted and overlaps the deep carbonate rocks that are also faulted and dislocated (Figure 13).

The unconfined or leaky SA has a thickness of a few meters to tens of meters. The SA exhibits a piezometric surface that is consistent with that of the wide CiminoVico aquifer system. In the study area, the SA is recharged by direct infiltration and groundwater inflow from the Cimino-Vico system, discharges locally in streams and in springs, and westward groundwater outflow occurs. The 


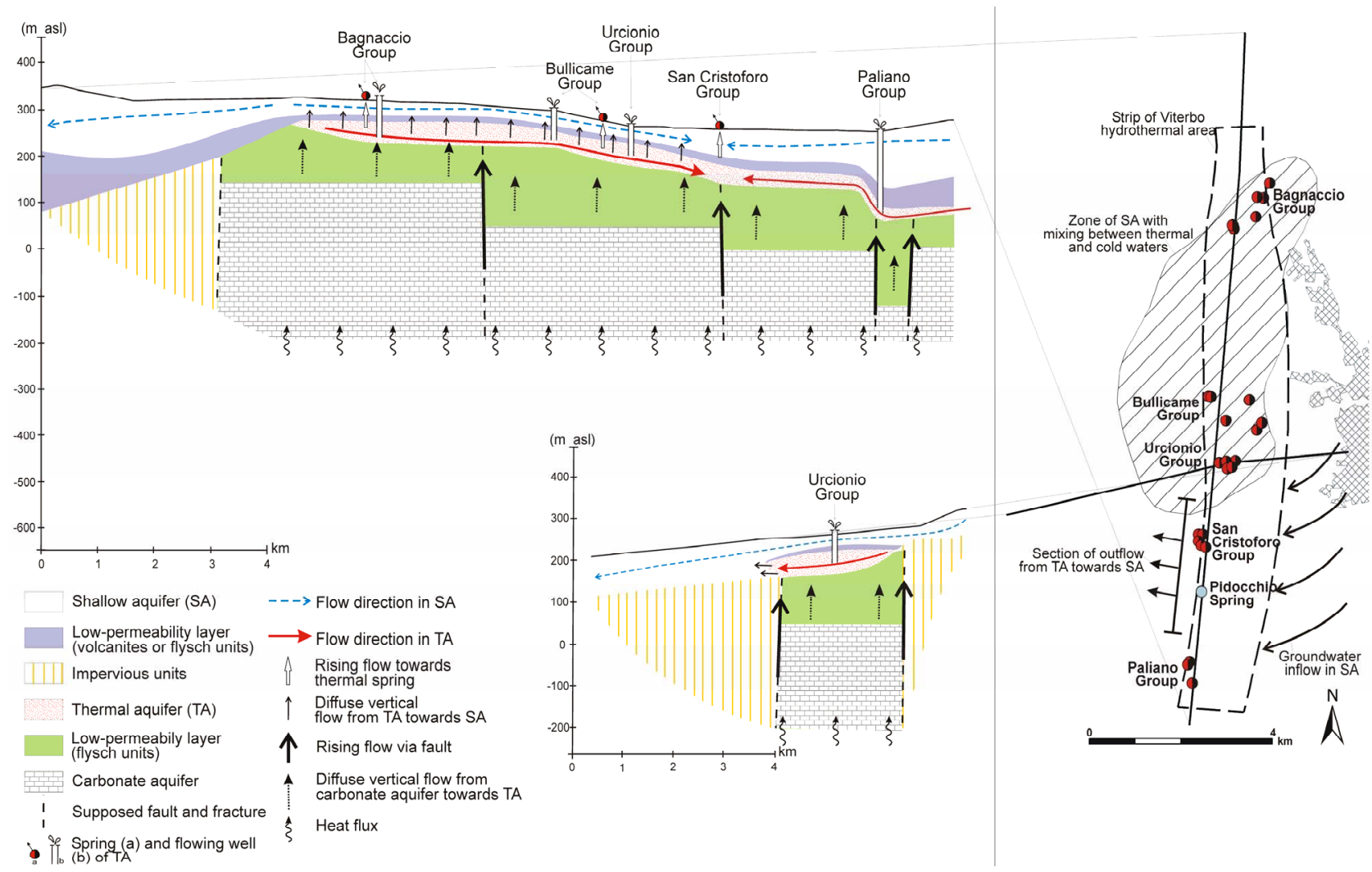

Figure 13. Hydrogeological conceptual model of the hydrothermal area of Viterbo showing the main groundwater paths in and among the overlapping aquifers. Zones considered for the evaluations of the yield of the groundwater system are shown on the right.

hydraulic parameters of the SA consist of transmissivity values between $10^{-5} \mathrm{~m}^{2} / \mathrm{s}$ and $10^{-2} \mathrm{~m}^{2} / \mathrm{s}$ and storativity values between $10^{-3}$ and $10^{-2}$.

Waters circulating in the SA are generally characterized by low temperature (less than $23^{\circ} \mathrm{C}$ ) and salinity (EC less than $700 \mu \mathrm{S} / \mathrm{cm}$ ) and are of bicarbonate-alkalineearth or bicarbonate-alkaline types, which suggests a short duration of the rock-water interaction. Sampled waters from the SA included a hydrochemical facies that arose from mixing between typical cold waters and thermal waters. These waters have been found in the northern and central zones of the study area, where the SA overlies the $\mathrm{TA}$, and in the western boundary of the hydrothermal area, where the TA has not been identified. In these zones, the flow from the TA influences $10 \%$ to $60 \%$ of the flow in the SA, based on sulfate and strontium concentrations.

The TA is located at a depth of up to $200 \mathrm{~m}$ and is characterized by thermal waters $\left(\mathrm{T}\right.$ of $40^{\circ} \mathrm{C}$ to $62^{\circ} \mathrm{C}$ ) with higher salinities (EC from 2800 to $3600 \mu \mathrm{S} / \mathrm{cm}$ ). The thickness of the volcanites and flysch units constituting the TA varies between 50 and $80 \mathrm{~m}$, even if other layers with thermal waters have been found in the same deep flysch units [53,54].

The TA has been identified within a rectangular area that is approximately $12 \mathrm{~km}$ long and $2 \mathrm{~km}$ wide (Figure
13), and it includes the following characteristics: 1) an uplift of sedimentary units underlying the volcanites; 2) a limited thickness of the same volcanic cover as the surroundings; 3) a fractured and faulted zone of the sedimentary basement; 4) a zone with one of the higher geothermal gradients in the Latium region (up to $100^{\circ} \mathrm{C} / \mathrm{km}$ ) and, therefore, a high heat flow (from 100 to $400 \mathrm{~mW} / \mathrm{m}^{2}$ ) $[1,26]$; and 5) an outcropping of thermogene travertine and $\mathrm{CO}_{2}$ emissions [33]. Within this N-S elongated zone, the TA is continuous (Figure 13). The southern boundary of the TA is not certain because the thermal waters have been intercepted by the Vico 2 Well in the volcanites (at a depth of 275 to $290 \mathrm{~m}$ ) [57] and, recently, in the flysch units $10 \mathrm{~km}$ south of the area under investigation.

The confined TA is characterized by two main directions of flow that converge westwards, and its hydraulic parameters consist of transmissivity values of $10^{-2} \mathrm{~m}^{2} / \mathrm{s}$ to $10^{-4} \mathrm{~m}^{2} / \mathrm{s}$ and a storativity of approximately $10^{-4}$. The hydraulic tests highlight the continuity of the TA and are in agreement with the results of production tests conducted in the 1950s [53,54].

The TA discharges into thermal springs and flowing wells. A diffuse vertical flow from the TA toward the SA through the aquitard also occurs, particularly in the northern and central zones of the strip where the two aquifers 
overlap, according to the vertical gradient between the two aquifers and the mixing highlighted by the chemical and isotopic data. Moreover, an outflow from the TA towards the SA occurs at its western boundary (Figure 13): 1) hydrostratigraphy highlights the lateral connection between the TA and the SA; 2) waters sampled from shallow wells show mixing with thermal waters; 3) the hydraulic heads of the TA and the SA are not as different. The northern and eastern boundaries of the TA do not present the full set of features.

Waters circulating in the TA are characterized by calcium-sulfate hydrochemical facies, a high dissolved gas content $\left(\mathrm{CO}_{2}\right.$ and $\left.\mathrm{H}_{2} \mathrm{~S}\right)$, high temperature and salinity. These features, together with those obtained from the analyses of the minor and trace constituents (such as $\mathrm{Sr}$ and $\mathrm{F}^{-}$), suggest deeper circuits and longer rock-water interactions compared with those occurring in the SA. The stability of the water quality based on the pumping tests and the chemical homogeneity of the thermal waters confirms the continuity of the TA. Isotopic analyses strengthen this hydrogeological conceptual model. The stable isotopes of water highlight the meteoric origin of the thermal waters and that their recharge area is similar to that of the SA. The waters of the two aquifers differ in residence time; the TA waters have an isotopic age of less than 50 - 60 years, which is approximately ten years older than the cold waters. Other chemical and isotopic indicators, such as the high sulfate and strontium content and $\delta^{34} \mathrm{~S}_{\mathrm{SO} 4}$ and $\delta^{18} \mathrm{O}_{\mathrm{SO} 4}$ values, can be explained through interactions with the fluid circulating in the deep carbonate basement.

The deep carbonates were recognized as the main reservoir of hot fluids feeding geothermal wells in the Vulsini volcanic area e.g., $[60,63]$, which is tens of kilometers from the study area. Documented evidence from four deep wells in and surrounding the area under examination confirms groundwater circulation in the carbonate aquifer $[38,53,54,57]$. Therefore, the deep carbonate aquifer can be considered to be a reservoir that recharges the TA, with a flow that mainly rises via faults and fractures in the sedimentary substratum of the volcanites because of the high heat flow that characterizes the region.

Considering the limited range of $\delta^{18} \mathrm{O}$ and $\delta^{2} \mathrm{H}$ in all waters sampled and the slight difference in tritium content between the thermal waters and those of the SA, the recharge area of the TA appears to be the same as that of the SA, i.e., the Lake Vico area of the Cimini Mountains. According to Piscopo et al. (2006) [37], this circuit seems to be consistent with the difference between the hydraulic head of the recharge area (approximately $500 \mathrm{~m} \cdot \mathrm{asl}$ ) and that determined for the thermal waters (from 225 and $320 \mathrm{~m} \cdot \mathrm{asl})$.

Based on previous conceptual models, the yield of the groundwater system was estimated with reference to the strip (Figure 13) in which the thermal waters flow out (surface area of $19.66 \mathrm{~km}^{2}$ ).

The total thermal water discharge $\left(Q_{t w}\right)$ can be written as

$$
Q_{t w}=Q_{s w}+Q_{v t}+Q_{l o}
$$

where

$Q_{s w}$ is the discharge into thermal springs and flowing wells;

$Q_{v t}$ is the vertical flow from the TA towards the SA, which occurs in the northern and central zones of the strip; and

$Q_{l o}$ is the flow from the TA towards the SA, which occurs mainly in the western boundary of the strip.

$Q_{s w}$ is approximately $84 \mathrm{~L} / \mathrm{s}$, considering the average discharge measured in 1983-84 and 2008-10 (Table 1).

$Q_{v t}$ can be evaluated by considering the direct infiltration in the northern and central zones of the SA $\left(I_{n c}\right)$, where mixing between thermal and cold waters has been found (Figure 13), and the ratio of the flows of the two end members derived from Equation (1), rewritten as $Q t / Q c$ :

$$
Q_{v t}=I_{n c} \cdot \frac{Q t}{Q c}
$$

$I_{n c}$ was estimated to be approximately $91 \mathrm{~L} / \mathrm{s}$, taking into account the following: 1) the surface area where mixing has been found $\left.\left(18.79 \mathrm{~km}^{2}\right) ; 2\right)$ the mean annual difference between the precipitation and actual evapotranspiration calculated for the northern and central zones (191 mm); and 3) an $I_{n c}$ equal to 0.8 of the difference between the precipitation and the actual evapotranspiration that is attributed to the flat topography of the area and the absence of streamflow for most of the year. The average $Q t / Q c$ for the area under examination is 0.75 , which gives a value of $68 \mathrm{~L} / \mathrm{s}$ for $Q_{v t}$.

$Q_{l o}$ can be evaluated by considering $Q t / Q i$ for the western zone of the SA beyond the boundary of the strip and the horizontal flow in the SA, which corresponds to $Q i$, by applying Darcy's Law for the section of outflow from the TA toward the SA (Figure 13). $Q_{l o}$ is approximately $53 \mathrm{~L} / \mathrm{s}$ because the flow in the SA is approximately $220 \mathrm{~L} / \mathrm{s}$ (if the mean transmissivity of this zone is considered, i.e., the mean obtained from the PT6, SD5 and SD6 tests in Table 2), and the average $Q t / Q i$ is 0.24 .

The total discharge of the thermal waters, $Q_{t w}$ is equal to $205 \mathrm{~L} / \mathrm{s}$.

The potential yield of the TA was independently estimated, taking into account the potentiometric surface and transmissivity values determined for the TA. Two sections of flow were considered according to the main flow directions. The first section is in the northern zone, and the second is in the southern zone of the strip; both sections were chosen to be distant from thermal springs and 
flowing wells. By assigning the lower values obtained from the pumping tests of the northern and southern sections and the proper values of the hydraulic gradient, a total flow rate of approximately $250 \mathrm{~L} / \mathrm{s}$ results from the application of Darcy's Law.

Although these evaluations may be subject to uncertainty because of the methods employed and the uncertainty in the data, it is clear that the yield of the TA is higher than what is discharged into the springs and wells. The TA can be considered to have a minimum yield of approximately $170 \mathrm{~L} / \mathrm{s}$ in the examined strip, even with a $30 \%$ error in Equation (2) (i.e., $Q_{v t}$ and $Q_{l o}$ ).

To complete the evaluation of the yield of the groundwater system, the mean potential direct recharge was estimated for the SA in the strip under examination. The result was approximately $98 \mathrm{~L} / \mathrm{s}$, which considers the mean annual difference between the precipitation and the actual evapotranspiration of the entire strip. The yield of the SA in the strip is higher than the direct recharge because of the groundwater inflow from the Cimino-Vico system in the eastern boundary of the strip. In the strip, the effective irrigation consumption from the SA can be evaluated by taking into account the difference between the potential $(841 \mathrm{~mm})$ and actual evapotranspiration $(577$ $\mathrm{mm}$ ) of the irrigated zones included in the strip (12.46 $\mathrm{km}^{2}$ ) and considering that the over-irrigation returns to the shallow aquifer. The estimated effective irrigation consumption is $104 \mathrm{~L} / \mathrm{s}$, which is comparable to the direct recharge.

\section{Conclusions}

The hydrogeological conceptual model seems to be more complex than the models presented previously in the literature. The shallowest $100-200 \mathrm{~m}$ of the two main aquifers, which are mainly tapped for drinking water, irrigation and spas, have been characterized. At a greater depth, another aquifer was recognized as the reservoir of the hot waters feeding the shallower waters. The hydraulic and chemical characteristics of the two shallower aquifers that were examined in detail in this study are very different. The first aquifer (SA) is related to the regional groundwater flow of the Cimino-Vico system, is hydraulically heterogeneous and is generally characterized by cold, fresh waters. The second aquifer (TA) is continuous within a strip in which the local hydrostratigraphic, structural and geothermal conditions allow a relatively active and constantly replenished flow of thermal waters with higher salinity. These two aquifers interact vertically and laterally, to give rise to mixed waters circulating in the first aquifer.

The yield of the groundwater system was estimated by an integrated hydrogeological and hydrochemical approach. In the examined strip, the yield of the TA is at least $170 \mathrm{~L} / \mathrm{s}$, and it discharges into thermal springs and wells and feeds the SA vertically and laterally. The SA is recharged by direct infiltration and inflow from regional groundwater as well as inflow from the second aquifer.

Based on the conceptual hydrogeological model and the previous estimate of the yield of the groundwater system, some preliminary considerations regarding groundwater management can be made.

Even if, at the scale of the whole groundwater flow system, the potential exists for future development of the $\mathrm{TA}$, then an increase in withdrawals through wells from the TA could result in a decrease in the discharge from the thermal springs, which has occurred in the past for some thermal springs and was verified during the pumping tests. Therefore, the future use of thermal waters must account for the potential yield of the TA and provide sufficient residual discharge at thermal springs for recreational use.

The effects of withdrawals from the SA on the entire groundwater system may also be important if it is considered that the flow rate necessary for irrigation in the strip is comparable to the direct recharge in the area. At the local scale, pumping from the SA could increase the vertical gradient between the two overlapping aquifers to cause an increase in flow from the TA toward the SA. This could cause an increase in the temperature and salinity of the SA that is tapped for irrigation and drinking water as well as a decrease in the flow rate of the thermal waters tapped to supply spas and for recreational use.

These examples highlight that, in the volcanic hydrogeological environment, one of the most stringent constraint in determining the correct usage of a resource is the co-existence of interacting groundwater flows of different qualities. However, in this fragile and complex hydrogeological system with a multi-purpose water demand, future decisions regarding groundwater management must also be based on economic, legal and environmental criteria to define the priorities for the use of different groundwater resources.

\section{Acknowledgements}

The authors are thankful to the Regione Lazio-Direzione Regionale Attività Produttive e Rifiuti, in the persons of Dr Mario Marotta, Eng Luigi Minicillo and Dr Patrizia Refrigeri, and Ministero dell'Istruzione, dell'Università e della Ricerca (Project PRIN-2008 - 2008YYZKEE_02) for financial support.

\section{REFERENCES}

[1] R. Cataldi, M. Mongelli, P. Squarci, L. Taffi, G. Zito and C. Calore, "Geothermal Ranking of Italian Territory," Geothermics, Vol. 24, No. 1, 1995, pp. 115-129. doi:10.1016/0375-6505(94)00026-9

[2] G. Bertrand, H. Celle-Jeanton, F. Huneau, S. Loock and 
C. Renac, "Identification of Different Groundwater Flowpaths within Volcanic Aquifers Using Natural Tracers for the Evaluation of the Influence of Lava Flows Morphology (Arghat Basin, Chaîne des Puys, France)," Journal of Hydrology, Vol. 391, No. 3-4, 2010, pp. 223-234. doi:10.1016/j.jhydrol.2010.07.021

[3] J. V. Cruz and M. O. Silva, "Hydrogeologic Framework of the Pico Island (Azores, Portugal)," Hydrogeology Journal, Vol. 9, No. 2, 2001, pp. 177-189. doi: $10.1007 / \mathrm{s} 100400000106$

[4] E. Custodio, "Groundwater Characteristics and Problems in Volcanic Rock Terrains," In: IAEA, Isotope Techniques on the Study of the Hydrology of Fractured and Fissured Rocks, STI/PUB 790, Vienna, 1989, pp. 87-137.

[5] E. Custodio, "Groundwater in Volcanic Rocks," In: Krasny, J. and J. M. Sharp, Eds., Groundwater in Fractured Rocks, Taylor and Francis Group, London, 2007

[6] V. Piscopo, V. Allocca and F. Formica, "Sustainable Management of Groundwater in Neapolitan Volcanic Areas, Italy," In: O. Sililo, et al., Eds., Groundwater: Past Achievements and Future Challenge, Balkema, Rotterdam, 2000.

[7] V. Piscopo, A. Baiocchi, S. Bicorgna and F. Lotti, "Hydrogeological Support for Estimation of the Sustainable Well Yield in Volcanic Rocks: Some Examples from Central and Southern Italy," Proceedings of 36th IAH Congress on Integrating Groundwater Science and Human Well-Ceing, Toyama, 26 October-1 November 2008, pp. 1652-1666.

[8] P. Ambrosetti, M. G. Carboni, M. A. Conti, A. Costantini, U. Esu Nicosia, G. Parisi and F. Sandrelli, "Evoluzione Paleogeografica e Tettonica dei BAcini Tosco-Umbro Laziali nel Pliocene e Nel Pleistocene Inferiore," Memorie della Società Geologica Italiana, Vol. 19, 1978, pp. 573-580.

[9] P. Baldi, F. A. Decandia, A. Lazzarotto and A. Calamai, "Studio Geologico del Substrato della Copertura Vulcanica Laziale Nella Zona dei Laghi di Bolsena, Vico e Bracciano," Memorie Società Geologica Italiana, Vol. 13, No. 4, 1974, pp. 575-606.

[10] F. Barberi, G. Buonasorte, R. Cioni, A. Fiordelisi, L. Foresi, S. Iaccarino, M. A. Laurenzi, A. Sbrana, L. Vernia and I. M. Villa, "Plio-Pleistocene Geological Evolution of the Geothermal Area of Tuscany and Latium," Memorie Descrittive della Carta Geologica d'Italia, Vol. 49, 1994, pp. 77-134.

[11] G. Marinelli, F. Barberi and R. Cioni, "Sollevamenti Neogenici e intrusioni acide della Toscana e del Lazio settentrionale," Memorie della Società Geologica Italiana, Vol. 49, 1993, pp. 279-288.

[12] L. Beccaluva, P. Di Girolamo and G. Serri, "Petrogenesis and Tectonic Setting of the Roman Volcanic Province, Italy," Lithos, Vol. 26, No. 3-4, 1991, pp. 191-221. doi:10.1016/0024-4937(91)90029-K

[13] S. Conticelli and A. Peccerillo, "Petrology and Geochemistry of Potassic and Ultrapotassic Volcanism in Central Italy: Petrogenesis and Inferences on the Evolution of the Mantle Sources," Lithos, Vol. 28, No. 3-6, 1992, pp. 221240. doi:10.1016/0024-4937(92)90008-M

[14] G. Marinelli, "Magma Evolution in Italy,” In: C. H. Squ- yres, Ed., Geology of Italy, The Earth Science Society of the Lybian Arab Republic, Tripoli, 1975, pp. 165-219.

[15] A. Peccerillo and P. Manetti, "The Potassium Alkaline Volcanism of Central-Southern Italy: A Review of the Data Relevant to Petrogenesis and Geodynamic Significance," Transactions of the Geological Society of South Africa, Vol. 88, No. 2, 1985, pp. 379-384.

[16] C. Cimarelli and D. de Rita, "Structural Evolution of the Pleistocene Cimini Trachytic Volcanic Complex (Central Italy)," Bulletin of Volcanology, Vol. 68, No. 6, 2006, pp. 538-548. doi:10.1007/s00445-005-0028-3

[17] D. Lardini and G. Nappi, "I Cicli Eruttivi del Complesso Vulcanico Cimino," Rendiconti della Società Italiana di Mineralogia e Petrologia, Vol. 42, 1987, pp. 141-153.

[18] F. Sollevanti, "Geologic, Volcanologic and Tectonic Setting of the Vico-Cimino Area, Italy," Journal of Volcanology and Geothermal Research, Vol. 17, No. 1-4, 1983, pp. 203-217. doi:10.1016/0377-0273(83)90068-9

[19] A. Bertagnini and A. Sbrana, "Il Vulcano di Vico: Stratigrafia del Complesso Vulcanico e Sequenze Eruttive Delle Formazioni Piroclastiche," Memorie della Società Geolologica Italiana, Vol. 35, No. 2, 1986, pp. 699-713.

[20] G. Nappi, L. Valentini and M. Mattioli, "Ignimbritic Deposits in Central Italy: Pyroclastic Products of the Quaternary Age and Etruscan Footpaths. Field Trip Guide Book-P09," Proceedings 32nd International Geological Congress, Florence, 20-28 August 2004, p. 32.

[21] G. Perini, S. Conticelli and L. Francalanci, "Inferences of the Volcanic History of the Vico Volcano, Roman Magmatic Province, Central Italy: Stratigraphic, Petrographic and Geochemical Data," Mineralogica et Petrographica Acta, Vol. 15, 1997, pp. 67-93.

[22] G. Buonasorte, M. G. Carboni and M. A. Conti, "Il Substrato Plio-Pleistocenico Delle Vulcaniti Sabatine: Considerazioni Stratigrafiche e Paleoambientali," Bollettino della Società Geologica Italiana, Vol. 110, No. 1, 1991, pp. 35-40.

[23] R. Funiciello, E. Locardi, G. Lombardi and M. Parotto, "The Main Volcanic Groups of Latium. Relations between Structural Evolution and Petrogenesis," Geologica Romana, Vol. 15, 1976, pp. 279-300.

[24] P. La Torre, R. Nannini and F. Sollevanti, "Geothermal Exploration in Central Italy: Geophysical Survey in Cimini Range Area," European Association of Exploration Geophysicists: 43th Meeting, Venezia, 26-29 May 1981.

[25] G. Buonasorte, A. Fiordelisi, E. Pandeli, U. Rossi and F. Sollevanti, "Stratigraphic Correlations and Structural Setting of the Pre-Neoautochtonous Sedimentary Sequences of Northern Latium," Periodico di Mineralogia, Vol. 56, 1987, pp. 111-122.

[26] A. Calamai, R. Cataldi, E. Locardi and A. Praturlon, "Distribuzione Delle Anomalie Geotermiche Nella Fascia Preappenninica Tosco-Laziale (Italia)," Symposium International Sobre Energia Geotérmica en America Latina, Ciudad de Guatemala, 16-23 October 1976, pp. 189-229.

[27] B. Della Vedova, G. Pellis, J. P. Foucher and J. P Rehault, "Geothermal Structure of Tyrrhenian Sea," Marine Geology, Vol. 55, No. 3-4, 1984, pp. 271-289. 
doi:10.1016/0025-3227(84)90072-0

[28] F. Mongelli, G. Zito, N. Ciaranfi and P. Pieri, "Interpretation of Heat Flow Density of the Apennine Chain, Italy," Tectonophysics, Vol. 164, No. 2-4, 1989, pp. 267-280. doi:10.1016/0040-1951(89)90020-6

[29] G. Chiodini, F. Frondini and L. Marini, "Theoretical Geothermometers and $\mathrm{P}_{\mathrm{CO}}$ Indicators for Aqueous Solutions Coming from Hydrothermal Systems of Medium-Low Temperature Hosted in Carbonate-Evaporite Rocks. Application to the Thermal Springs of the Etruscan Swell, Italy," Applied Geochemistry, Vol. 10, No. 3, 1995, pp. 337-346. doi:10.1016/0883-2927(95)00006-6

[30] G. Chiodini, F. Frondini and F. Ponziani, "Deep Structures and Carbon Dioxide Degassing in Central Italy," Geothermics, Vol. 24, No. 1, 1995, pp. 81-94. doi:10.1016/0375-6505(94)00023-6

[31] V. Duchi and A. Minissale, "Distribuzione Delle Manifestazioni Gassose Nel Settore Peritirrenico Tosco-Laziale e Loro Interazione con gli Acquiferi Superficiali," Bollettino della Società Geologica Italiana, Vol. 114, No. 2, 1995, pp. 337-351.

[32] A. Minissale and V. Duchi, "Geothermometry on Fluids Circulating in a Carbonate Reservoir in North-Central Italy," Journal of Volcanology and Geothermal Research, Vol. 35, No. 3, 1988, pp. 237-252. doi:10.1016/0377-0273(88)90020-0

[33] A. Minissale, D. M. Kerrick, G. Magro, M. T. Murell, M. Paladini, S. Rihs, N. C. Sturchio, F. Tassi and O. Vaselli, "Geochemistry of Quaternary Travertines in the Region North of Rome (Italy): Structural, Hydrologic and Paleoclimatic Implications," Earth and Planetary Science Letters, Vol. 203, No. 2, 2002, pp. 709-728. doi:10.1016/S0012-821X(02)00875-0

[34] A. Baiocchi, W. Dragoni, F. Lotti, G. Luzzi and V. Piscopo, "Outline of Theology of the Cimino and Vico Area and of the Interaction between Groundwater and Lake Vico (Lazio Region, Central Italy)," Bollettino della Società Geologica Italiana, Vol. 125, No. 2, 2006, pp. 187202.

[35] C. Boni, P. Bono and G. Capelli, "Schema Idrogeologico Dell'Italia Centrale," Memorie della Società Geologica Italiana, Vol. 35, No. 2, 1986, pp. 991-1012.

[36] G. Capelli, R. Mazza and C. Gazzetti, "Strumenti e Strategie per la Tutela e l'uso Compatibile Della Risorsa Idrica del Lazio: Gli Acquiferi Vulcanici,” Pitagora, Bologna, 2005.

[37] V. Piscopo, M. Barbieri, V. Monetti, G. Pagano, S. Pistoni, E. Ruggi and D. Stanzione, "Hydrogeology of Thermal Waters in Viterbo Area, Central Italy," Hydrogeology Journal, Vol. 14, No. 8, 2006, pp. 1508-1521. doi:10.1007/s10040-006-0090-8

[38] U. Chiocchini, F. Castaldi, M. Barbieri and V. Eulilli, "A Stratigraphic and Geophysical Approach to Studying the Deep-Circulating Groundwater and Thermal Springs, and Their Recharge Areas, in Cimini Mountains-Viterbo Area, Central Italy," Hydrogeology Journal, Vol. 18, No. 6, 2010, pp. 1319-1341. doi:10.1007/s10040-010-0601-5

[39] P. Baldi, G. C. Ferrara, L. Masselli and G. Pieretti, "Hydrogeochemistry of the Region between Monte Amiata and Rome," Geothermics, Vol. 2, No. 3-4, 1973, pp. 124141. doi:10.1016/0375-6505(73)90020-5

[40] M. Angelone, C. Cremisini, V. Piscopo, M. Proposito and F. Spaziani, "Influence of Hydrostratigraphy and Structural Setting on the Arsenic Occurrence in Groundwater of the Cimino-Vico Volcanic Area (Central Italy)," Hydrogeology Journal, Vol. 17, No. 4, 2009, pp. 901-914. doi:10.1007/s10040-008-0401-3

[41] G. Capasso and S. Inguaggiato, "A Simple Method for the Determination of Dissolved Gases in Natural Waters. An Application to Thermal Waters from Volcano Island," Applied Geochemistry, Vol. 13, No. 5, 1998, pp. 631-642. doi:10.1016/S0883-2927(97)00109-1

[42] S. Epstein and T. Mayeda, "Variation of ${ }^{18} \mathrm{O}$ Content of Water from Natural Sources," Geochimica et Cosmochimica Acta, Vol. 4, No. 5, 1953, pp. 213-224. doi:10.1016/0016-7037(53)90051-9

[43] F. Yanagisawa and H. Sakai, "Preparation of $\mathrm{SO}_{2}$ for Sulfur Isotope Ratio Measurements by the Thermal Decomposition of $\mathrm{BaSO}_{4}-\mathrm{V}_{2} \mathrm{O}_{5}-\mathrm{SiO}_{2}$ Mixtures," Analytical Chemistry, Vol. 55, No. 6, 1983, pp. 985-987. doi: $10.1021 / \mathrm{ac} 00257 \mathrm{a} 046$

[44] M. P. Neary, "Tritium Enrichment-To Enrich or Not to Enrich?" Radioactivity and Radiochemistry, Vol. 8, 1997, pp. 23-35.

[45] SIMN, “Annali Idrologici," Servizio Idrografico e Mareografico Nazionale, Ministero dei Lavori Pubblici, Roma, 1951-1999.

[46] Regione Lazio, “Annali Idrologici,” Ufficio Idrografico e Mereografico Regione Lazio, Roma, 2000-2010.

[47] G. Allen, S. Pereira, D. Raes and M. Smith, "Crop Evapotranspiration-Guidelines for Computing Crop Water Requirements," Natural Resources Management and Environment Department, FAO, Rome, 1998.

[48] C. T. Haan, "Statistical Methods in Hydrology," The Iowa State University Press, Ames, 1977.

[49] S. Carnicelli, D. Sagri, U. Chiocchini and S. Madonna, "Geopedologia," In: U. Chiocchini, Ed., La Geologia Della Città di Viterbo, Cangemi Editore, Roma, 2004.

[50] P. Lorenzoni, M. Raglione, P. Quantin, D. Bidini and L. Lulli, "Studio Dell'Apparato Vulcanico di Vico (Lazio). IV. I Suoli Delle Colate Piroclastiche," Annali Istituto Sperimentale di Studio e Difesa Suolo Firenze, Vol. 16, 1985, pp. 199-226.

[51] L. Lulli, C. Blasi, G. Abate, D. Bidini, S. Fascetti, P. Lorenzoni and M. Marchetti, "Studio Pedologico Dell'Apparato Vulcanico di Vico (Lazio). VIII. L'effetto Della Vegetazione Sulla Genesi dei Suoli," Annali Istituto Sperimentale di Studio e Difesa Suolo Firenze, Vol. 17, 1986, pp. 159-172.

[52] Regione Lazio, "Carta di Uso del Suolo," Direzione Regionale Territorio e Urbanistica, Regione Lazio, Roma, 2003.

[53] B. Conforto, "Risultati Della Prima Fase di Ricerche di Forze Endogene nel Viterbese," L'Ingegnere, Vol. 27, 1954, pp. 345-350.

[54] B. Conforto, "Risultati Della Prima Fase di Ricerche di Forze Endogene nel Viterbese," L'Ingegnere, Vol. 27, 
1954, pp. 521-530.

[55] P. P. Mattias and V. Ventriglia, "La Regione Vulcanica dei Monti Cimini e Sabatini," Memorie della Società Geolologica Italiana, Vol. 9, No. 3, 1970, pp. 331-384.

[56] B. Toro, "Anomalie Residue di Gravità e Strutture Profonde Nelle Aree Vulcaniche del Lazio Settentrionale," Geologica Romana, Vol. 17, 1978, pp. 35-44.

[57] B. Camponeschi and F. Nolasco, "Le Risorse Naturali Della Regione Lazio. 2 Monti Cimini e Tuscia Romana," Regione Lazio, Roma, 1984.

[58] G. Buonasorte, R. Cataldi, A. Ceccarelli, A. Costantini, S. D’Offizi, A. Lazzarotto, A., Ridolfi, P. Baldi, A. Borelli, G. Bertini, R. Bertrami, A. Calamai, G. Cameli, R. Corsi, C. D'Acquino, A. Fiordelisi, A. Grezzo and F. Lovari, "Ricerca ed Esplorazione Nell'Area Geotermica di Torre Alfina (Lazio-Umbria)," Bollettino della Società Geologica Italiana, Vol. 107, No. 2, 1988, pp. 265-337.

[59] G. Buonasorte, E. Pandeli and A. Fiordelisi, "The Alfina 15 Well: Deep Geological Data from Northern Latium (Torre Alfina Geothermal Area)," Bollettino della Società Geologica Italiana, Vol. 110, No. 3-4, 1991, pp. 823-831.

[60] R. Cataldi and M. Rendina, "Recent Discovery of a New Geothermal Field: Alfina," Geothermics, Vol. 2, No. 3-4, 1973, pp. 106-116. doi:10.1016/0375-6505(73)90016-3

[61] G. Cavarretta, G. Giannelli, G. Scandiffio and F. Tecce, "Evolution of the Latera Geothermal System II: Metamorphic Hydrothermal Mineral Assemblages and Fluid Chemistry," Journal of Volcanology and Geothermal Research, Vol. 26, No. 3-4, 1985, pp. 337-364. doi:10.1016/0377-0273(85)90063-0

[62] V. Duchi, L. Matassoni, F. Tassi and B. Nisi, "Studio Geochimico dei Fluidi (Acque e Gas) Circolanti Nella Regione Vulcanica dei M.ti Vulsini (Italia Centrale)," Bollettino della Società Geologica Italiana, Vol. 122, No. 1, 2003, pp. 47-61.

[63] G. Giannelli and G. Scandiffio, "The Latera Geothermal System (Italy): Chemical Composition of the Geothermal Fluid and Hypotheses on Its Origin," Geothermics, Vol. 18, No. 3, 1989, pp. 447-463. doi:10.1016/0375-6505(89)90068-0

[64] G. F. Pinder and J. F. Jones, "Determination of the Groundwater Component of Peak Discharge from Chemistry of Total Runoff," Water Resources Research, Vol. 5, No. 2, 1969, pp. 438-445. doi:10.1029/WR005i002p00438

[65] H. Craig, "Isotopic Variations in Meteoric Water," Science, Vol. 133, No. 3465, 1961, pp. 1702-1703. doi:10.1126/science.133.3465.1702

[66] A. Longinelli and E. Selmo, "Isotopic Composition of Precipitation in Italy: A First Overall Map," Journal of Hydrology, Vol. 270, No. 1-2, 2003, pp. 75-88.

[67] I. D. Clark and P. Fritz, "Environmental Isotopes in Hydrogeology," Lewis Publishers, New York, 1997.

[68] C. W. Thornthwaite, "An Approach toward a Rational Classification of Climate," Geographical Review, Vol. 38, No. 1, 1948, pp. 55-94. doi:10.2307/210739

[69] C. W. Thornthwaite and J. R. Mather, "The Water Balance," Publication in Climatology, Vol. 8, No. 1, 1955. 